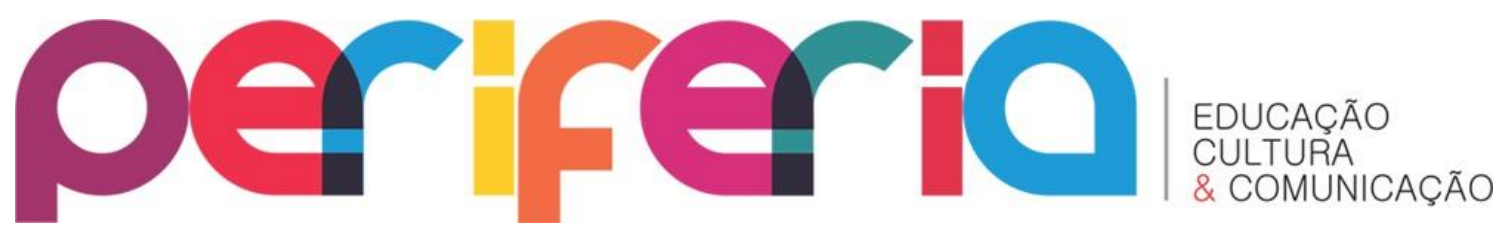

ISSN:1984-9540

DOI: 10.12957/periferia.2019.39384

\title{
CIBERLEITURA NA EDUCAÇÃO BÁSICA: REALIDADE POSSÍVEL?
}

\author{
Bruna Rafaela Evangelista de Oliveira ${ }^{1}$ \\ Universidade do Estado do Rio Grande do Norte - UERN \\ Mayra Rodrigues Fernandes Ribeiro ${ }^{2}$ \\ Universidade do Estado do Rio Grande do Norte
}

\section{Resumo}

Este artigo apresenta uma discussão sobre a leitura na cibercultura com base em uma pesquisa desenvolvida na Escola Estadual Antônio Gomes. Tem como objetivo mobilizar dispositivos de leitura que potencializem os multiletramentos de alunos do $5^{\circ}$ ano do ensino fundamental. Para o desenvolvimento desse estudo trazemos a pesquisa-formação na cibercultura (SANTOS, 2014) com a concepção de uma pesquisa que se faz em ato, junto com o sujeito, na relação cidade-ciberespaço. Inspiramonos na abordagem multirreferencial (ARDOINO, 1998) na qual tecemos as redes de formação juntos com os sujeitos, construindo um olhar plural dos processos formativos, implicados como sujeitos-atores-autores em formação. Nesse processo nos afastamos de uma concepção de ciência que enquadra os conhecimentos em um padrão pré-definido e nos aproximamos de um "rigor outro" (MACEDO; GALEFFI; PIMENTEL, 2009), que considera as heterogeneidades dos sujeitos como parte do processo formativo e a diferença como potência na construção do conhecimento. A cibercultura entra assim como contexto que situa a pesquisa em uma cultura que faz parte do cotidiano, e como espaço de produção de conhecimento. Como metodologia apresentamos a leitura na cibercultura, os diálogos com professores e alunos e os dispositivos mobilizados para a potencialização das práticas de leitura. Concluímos que as práticas de leituras com uso das tecnologias digitais não são uma solução linear para os problemas de aprendizagens de leitura e escrita na escola, mas quando mediadas e intencionais possibilitam uma motivação e uma melhora gradativa na comunicação e produção de textual pelos alunos da educação básica.

Palavras-chave: Leitura na Cibercultura. Dispositivos de formação. Ciberleitor.

\footnotetext{
${ }^{1}$ Aluna regular e Bolsista de Demanda Social CAPES do Mestrado em Educação do Programa de Pósgraduação em Educação- POSEDUC, da Universidade do Estado do Rio Grande do Norte - UERN. Mossoró, Rio Grande do Norte/Brasil. brunaevangelista03@gmail.com

2 Doutora em Educação pela Universidade do Rio de Janeiro. Professora da Faculdade de Educação FE, na Universidade do Estado do Rio Grande do Norte. Mossoró, Rio Grande do Norte/Brasil. mayra.rfr@gmail.com
} 


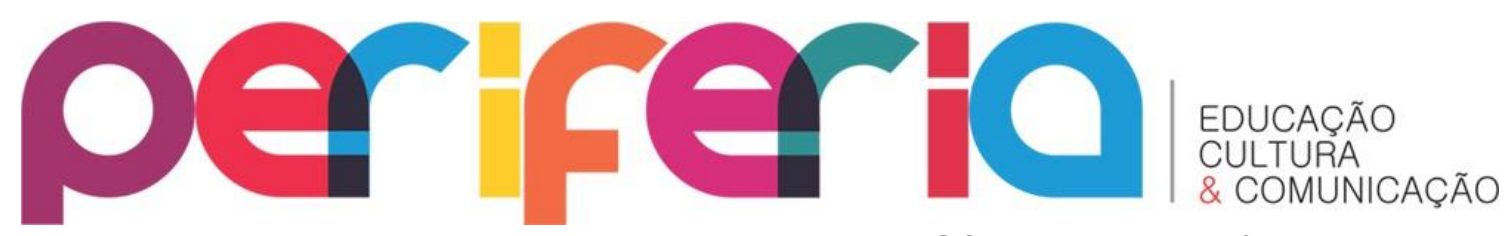

ISSN:1984-9540

DOI: $10.12957 /$ periferia.2019.39384

\title{
CYBERLEARNING IN BASIC EDUCATION: POSSIBLE REALITY?
}

\begin{abstract}
This article presents a discussion about reading in cyberculture, based on a research developed at the Antônio Gomes State School, that has as function mobilize reading devices that facilitate the multilearning of students from the 5th year of primary education. For the development of this study, training the cyberculture conception (SANTOS, 2014) research that is done with the subject, in the relation citycyberspace. Based on the approach multireferencial (ARDOINO, 1998) in which buillt the training networks together with the subjects, constructing a plural view of the formative processes, implied as subject-actors-authors in formation. In this process we move away of a science that fits the knowledge into a pre-defined pattern, and brought near of a "rigor other" (MACEDO; GALEFFI; PIMENTEL, 2009), which considers the heterogeneities of the subjects as part of the formative process and the difference as power in the construction of knowledge. The cyberculture is then a context that research in a culture that does part of everyday life, and as a production space of knowledge. In this context we present the reading in cyberculture, the dialogues with teachers and students, the devices mobilized for this study, together perception as these devices were felt by students. Conclude that Reading practices with use tecnologies of digital are not effective soluction to the problems to readindg learning in the school but if mediated with goal allow a motivation and gradual improvementin communication and textual prodiction by students of basic education.
\end{abstract}

Keywords: Reading in Cyberculture. Training devices. Cyberreader 


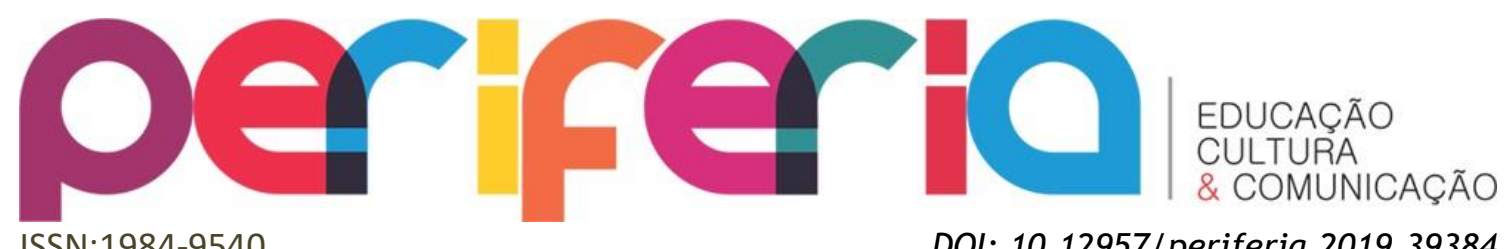

CIBERLECTURA EN LA EDUCACIÓN BÁSICA: ¿REALIDAD POSIBLE?

\section{Resumen}

Este artículo presenta una discusión sobre la lectura en la cibercultura con base en una investigación desarrollada en la Escuela Estadual Antônio Gomes. Tiene como objetivo movilizar dispositivos de lectura que potencien los multiletramentos de alumnos del $5^{\circ}$ año de la enseñanza fundamental. Para el desarrollo de este estudio traemos la investigación-formación en la cibercultura (SANTOS, 2014) con la concepción de una investigación que se hace en acto, junto con el sujeto, en la relación ciudad-ciberespacio. Nos inspira en el enfoque multirreferencial (ARDOINO, 1998) en el que tejemos las redes de formación junto con los sujetos, construyendo una mirada plural de los procesos formativos, implicados como sujetos-actoresautores en formación. En este proceso nos alejamos de una concepción de ciencia que enmarca los conocimientos en un patrón predefinido y nos acercamos a un "rigor otro" (MACEDO, GALEFFI, PIMENTEL, 2009), que considera las heterogeneidades de los sujetos como parte del proceso formativo y, la diferencia como potencia en la construcción del conocimiento. La cibercultura entra así como contexto que sitúa la investigación en una cultura que forma parte de lo cotidiano, y como espacio de producción de conocimiento. Como metodología presentamos la lectura en la cibercultura, los diálogos con profesores y alumnos y los dispositivos movilizados para la potenciación de las prácticas de lectura. Concluimos que las prácticas de lecturas con uso de las tecnologías digitales no son una solución lineal para los problemas de aprendizaje de lectura y escritura en la escuela, pero cuando mediadas e intencionales posibilitan una motivación y una mejora gradual en la comunicación y producción de textual por los alumnos de la educación básica.

Palabras clave: Lectura en la Cibercultura. Dispositivos de formación. Cyber-lector. 


\section{per

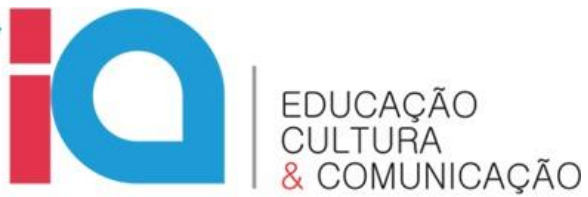

ISSN:1984-9540

DOI: $10.12957 /$ periferia.2019.39384

\section{LEITURA NA CIBERCULTURA: DEMANDAS DO DIGITAL EM REDE}

O processo de aquisição da leitura e da escrita foi e ainda é um grande dilema da educação básica e de professores que atuam no início da escolarização com o processo de alfabetização. Alfabetizar, letrar, alfabetizar letrando são alguns conceitos carregados de sentidos políticos e pedagógicos presentes nas políticas de alfabetização, nos livros didáticos e nas práticas cotidianas dos professores na sala de aula.

Com as mudanças culturais, sociais e tecnológicas os dilemas da docência também mudam, diante de uma cenário plural de informações e letramentos que se fazem cada vez mais presentes no cotidiano das pessoas, as práticas de leitura ganham outras demandas, mas alguns dilemas permanecem como uma espécie de Déjà vu, como é o caso da ausência de interesse das crianças pelas práticas de leitura disponibilizadas na escola, como consequência, poucas desenvolvem habilidades de escrita e compreensão textual.

Essa realidade é reflexo de uma sociedade com poucos hábitos de leitura, como mostra o resultado da pesquisa Retratos da Leitura no Brasil, que revela que $44 \%$ da população brasileira não lê e 30\% nunca comprou um livro. O brasileiro lê apenas 4,96 livros por ano, desses, 0,94\% são indicados pela escola e 2,88\% lidos por vontade própria. Para a pesquisa, é leitor quem leu, inteiro ou em partes, pelo menos 1 livro nos últimos 3 meses. Dados esses que nos fazem refletir sobre a importância da leitura na formação dos sujeitos.

A leitura é para nós inspiração de pesquisa e estudo em tempo de cibercultura. As tecnologias digitais nos colocam diante da era da comunicação multimodal, na qual o leitor utiliza uma diversidade de linguagens para muito além das letras. A competência linguística da codificação e decodificação, interpretação e compreensão da escrita, importante recurso semiótico, é apenas uma das habilidades necessárias para a complexa comunicação no mundo digital. Nesse sentido, este trabalho traz como problematizações principal e secundárias, respectivamente: 


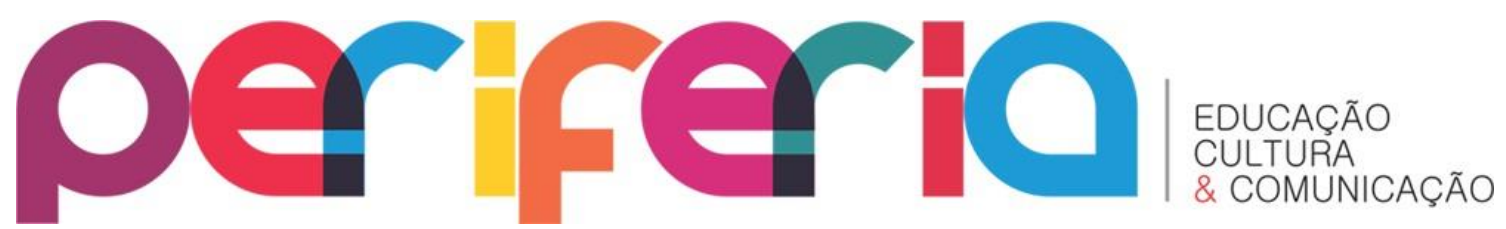

ISSN:1984-9540

DOI: 10.12957/periferia.2019.39384

como pensarfazer ${ }^{3}$ práticas de leitura que potencializem a interação e o gosto pela leitura na cibercultura? No contexto da cultura digital em rede como as crianças lidam com a leitura? Quais práticas de leitura são desenvolvidas e estimuladas na escola? Como mobilizar dispositivos de leitura podem potencializar os multiletramentos dos alunos?

A leitura enquanto capacidade humana de decodificar a escrita, de compreendê-la e de ressignificá-la, vem mudando com o decorrer da história. Com a emergência da cibercultura, envoltos por novas práticas, técnicas, linguagens e letramentos, a leitura se expande e se reconfigura em novos formatos. Ao se descolar das páginas dos livros impressos para as telas eletrônicas, propõe uma nova demanda para a leitura na sociedade, que se inicia com a emergência do videotexto ${ }^{4}$, que marca a passagem da escrita do papel para a tela eletrônica (SANTAELLA, 2013).

Esse novo contexto da leitura inquieta a sociedade e revoluciona a forma técnica de produção dos textos, o suporte do escrito e as práticas de leitura (CHARTIER, 2002). Diante da era da mobilidade ubíqua ${ }^{5}$, circulamos com a pluralidade de linguagens e mídias nos espaços urbanos e nas infovias das redes, em um tempo em que o acesso a informação está a distância de um clique, em formatos de textos que adquirem uma nova dinâmica interativa adequados a praticidade e mobilidade da internet. Nesse cenário, as crianças da chamada geração $Z^{6}$, apresentam uma enorme facilidade de interação com as interfaces digitais, bastam apenas ter acesso aos recursos sociotécnicos.

\footnotetext{
${ }^{3}$ A junção da palavra ganha inspiração nos estudos de Alves (2003) que considera importante para marcar os sentidos que buscam superar a dicotomização herdada na racionalidade da ciência moderna. Esse e outros neologismos apresentados no texto expressam a busca pela ruptura com os princípios de uma dicotomia "naturalizada" nas formas de ver e expressar o conhecimento e marcam a força política das palavras quando engendradas de sentidos.

${ }^{4} \mathrm{O}$ videotexto é um sistema de distribuição bidirecional de informação para um mercado de massa, dentro do qual usuários podem solicitar informação a uma tela de televisão de um banco de dados dos em computador através de um teclado. É uma das primeiras redes que permite que as pessoas recebam e interajam com a informação, disponibilizada na tela de TV (PLAZA, 1986). (Disponível em: <http://www.mac.usp.br/mac/expos/2013/julio_plaza/pdfs/descricao_do_videotexto.pdf>. Acesso em: 22 ago. 2018.)

${ }^{5}$ Estamos na era da conexão, da mobilidade ubíqua, a comunicação em deslocamento, que se caracteriza pela conexão constante em toda a parte na relação cidade-ciberespaço (SANTOS, 2014)

${ }^{6}$ Geração que nasceu na era das tecnologias digitais, muito familiarizadas com a internet.
} 


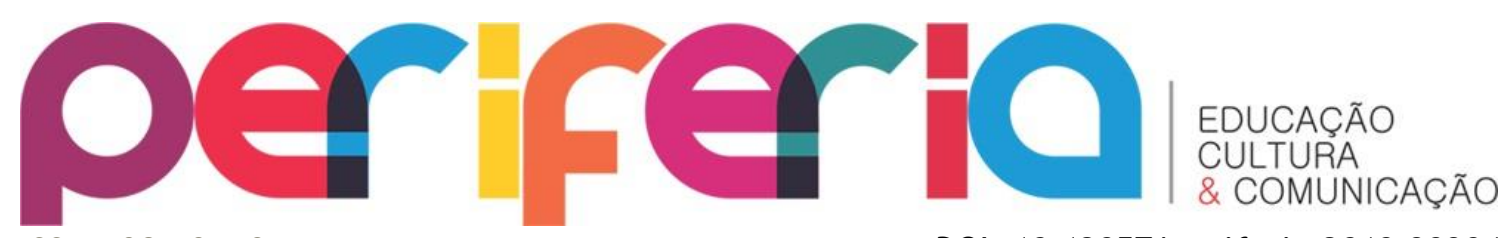

ISSN:1984-9540

DOI: $10.12957 /$ periferia.2019.39384

As novas formas de comunicação e interação com a informação e com o entretenimento é perceptível nas atividades cotidianas das crianças, que mesmo não tendo o domínio dos códigos linguísticos alfabéticos, lançam mão de habilidades de oralidade para o envio de mensagens e produção de vídeos via seus dispositivos móveis ou de seus pais ou responsáveis, e ainda, dominam os games com muita desenvoltura. Assim, é possível encontrar crianças no $5^{\circ}$ ano do Ensino Fundamental, como é o caso de alguns alunos da escola lócus da pesquisa em discussão, que não mobilizam conhecimentos para a escrita de um texto no papel, mas que passam longas mensagens em áudio e produzem vídeos com conteúdo diversos do seu interesse. Na figura 1, uma expressão dessa habilidade:

Figura 1 canal no youtuber de aluno da escola

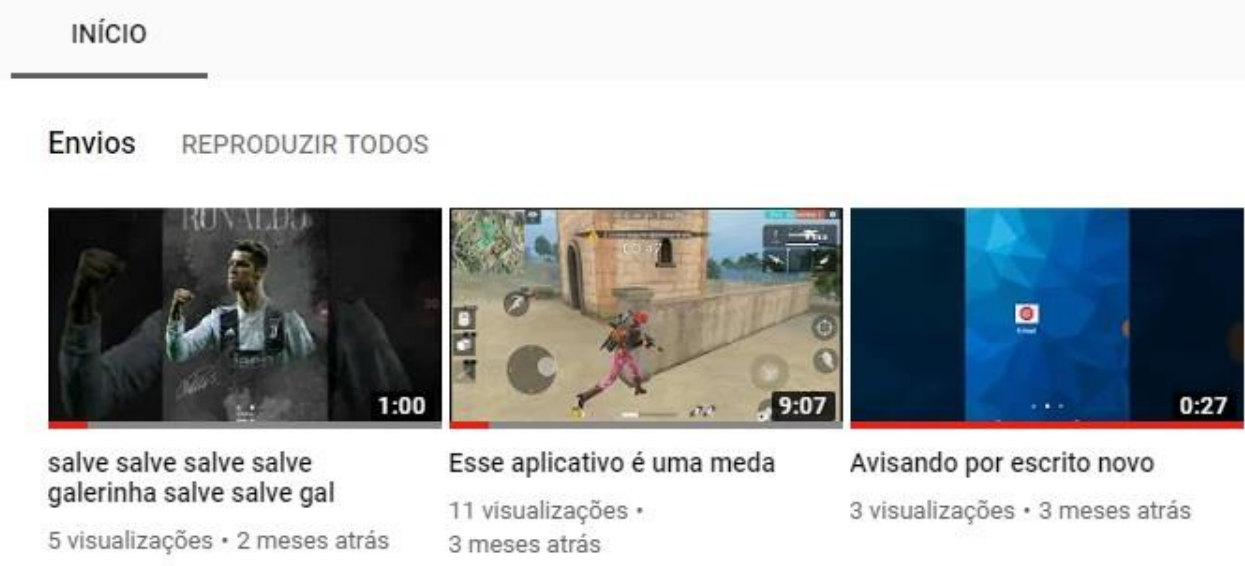

Playlists criadas

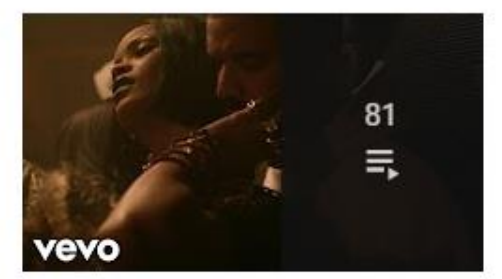

Erik

Rihanna - Work (Explicit) ft. Drake $\cdot 7: 35$

Fifth Harmony - Work from Home ft. Ty Dolla \$ign • 3:40

VER A PLAYLIST COMPLETA (81 VIDEOS)

Fonte: https://www.youtube.com/channel/UCc8H4O4_Xzf-YB12YCB6MCW

Essa realidade reflete um cenário multimodal, em que as crianças navegam pelos espaços não lineares da internet e produzem novas formas de comunicação e interação, desenvolvem novas habilidades de leitura que transcende as páginas dos 


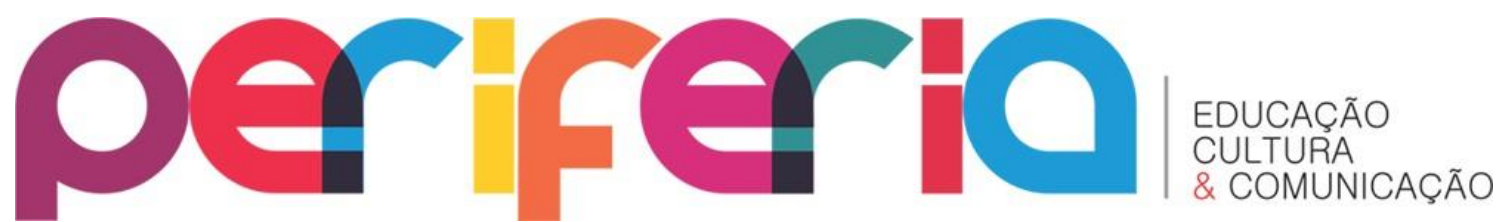

ISSN:1984-9540

DOI: $10.12957 /$ periferia.2019.39384

livros. As múltiplas linguagens se entrelaçam, criando novas formas de letramentos que ampliam e diversificam as possibilidades formativas. Essa realidade demanda habilidades outras dos sujeitos para significar o uso cotidiano das redes digitais, desenvolver habilidades de produção de conhecimento plural dentro e fora do ciberespaço ${ }^{7}$, e um olhar crítico e reflexivo sob os letramentos disponíveis nas redes digitais são fundamentais para a formação cidadã.

Essas premissas e afirmações apresentadas nos levam a pensarmos sobre o papel da escola na formação do leitor no contexto da cibercultura. A formação inicial e continuada ou em serviço precisa considerar a importância de ampliar, para além dos usos cotidianos que os professores fazem das tecnologias digitais, outras formas de letramento digital, para que possam inserir em seus planejamentos e em suas práticas recursos multimodais, aplicativos que instiguem a criatividade e motivem os alunos no desenvolvimento de habilidades textuais. Essa necessidade é sentida pelos professores da educação básica, como podemos perceber em suas narrativas

Agora assim, eu não trabalho aqui diretamente com os alunos, eu sou temporária, mas o assunto abordado ele é muito bom, porque nós temos essa dificuldade, por exemplo: eu trabalho em duas escolas, e às vezes eu preciso de uma música, aí eu pesquiso a música na minha casa, ligo para minha colega, e peço para ela baixar a música para mim, porque eu ainda não sei fazer, então quando vocês começaram a falar, realmente é uma realidade, que eu acho que em todas as escolas deveria dar o primeiro passo. Por que é necessário para que um dia os nossos alunos não estejam assim: "ah to precisando de algo, vou ligar para fulano e fulano vai fazer isso para mim, porque eu não sei fazer", quer dizer nós somos bastante analfabetos nessa área. Eu sou da fase pré-silábica, então assim é realidade hoje, e quem não acompanha fica para trás. (PROFESSORA 2, 2017)

Desse modo, os professores sentem as demandas que surgem diante desse cenário e compreendem que em uma sociedade mediada pelas informações, em que os sujeitos vivem a era da cibercultura e dos multiletramentos, não há como a escola, enquanto espaço de produção de conhecimento e interação social, ficar alheia ao

\footnotetext{
${ }^{7} 0$ que caracterizam os ciberespaços são espaços mediados pelas tecnologias digitais, que abrangem o que na interconexão mundial de computadores representa as inúmeras informações disponíveis nas redes (LÉVY, 1999).
} 


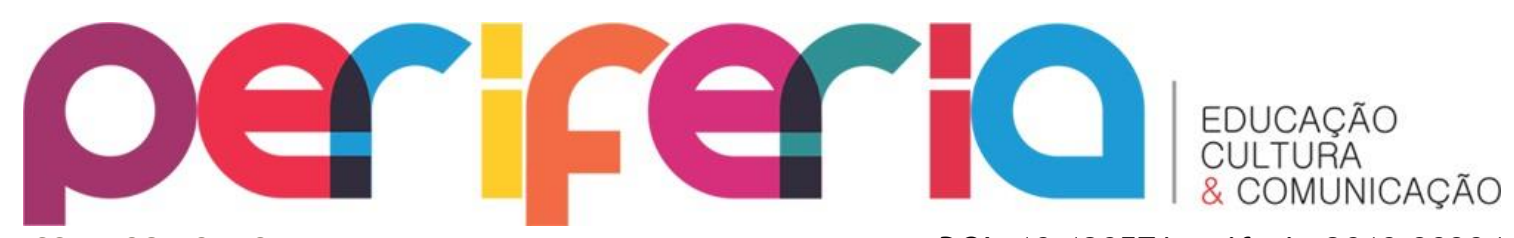

ISSN:1984-9540

DOI: $10.12957 /$ periferia.2019.39384

que se passa nesse cenário. Portanto, diante das demandas sentidas/vividas/percebidas com a emergência da cibercultura, pretendemos ir ao encontro dos sujeitos praticantes dessa cultura, que dialogam e vivem essas mudanças, e estão como desejantespraticantes de saberesfazeres que potencializem suas aprendizagens situadas em uma formação para/na vida.

\section{Professores e alunos desejantespraticantes de saberesfazeres na cibercultura}

Apresentamos nessa tessitura uma pesquisa com uma proposta outra de fazer ciência, pautada no próprio estudo crítico do conhecimento científico que se baseia em uma forma de fazer ciência com um "rigor outro" (MACEDO; GALEFFI; PIMENTEL, 2009). Um rigor que se afasta da verdade-mundo já consolidada e definitiva, do "rigor" que se faz no distanciamento entre sujeito e "objeto" de pesquisa e de uma concepção de ciência que é colocada como inflexível negando as particularidades do sujeito e os considerando como imutáveis e previsíveis. Nesse sentido, a pesquisa com um rigor outro desengessa o pesquisador de uma possível linearidade e o conduz a caminhos outros de produção de conhecimento, que se fazem junto com os sujeitos na relação cotidiana.

O rigor proposto nessa tessitura textual e de pesquisa não se define em uma única forma de fazer ciência e nem pretende definir os caminhos para o encontro com a verdade, pelo contrário, propõe que criemos caminhos diferentes de produzir conhecimentos, na relação mútua de aprendizagem entre os sujeitos da pesquisa. Dessa forma, os percursos metodológicos aqui apresentados não foram definidos a priori, como uma receita a ser seguida, mas se produz em ato, no contexto da pesquisa, com direito a mudança de itinerário, pois é fazendosentindo a pesquisa que se produz sentido. Diante dessa perspectiva, apresentamos na figura 20 infográfico com a metodologia tecida no dentro/fora da escola, junto com os sujeitos “praticantes culturais” (CERTEAU, 2011). 


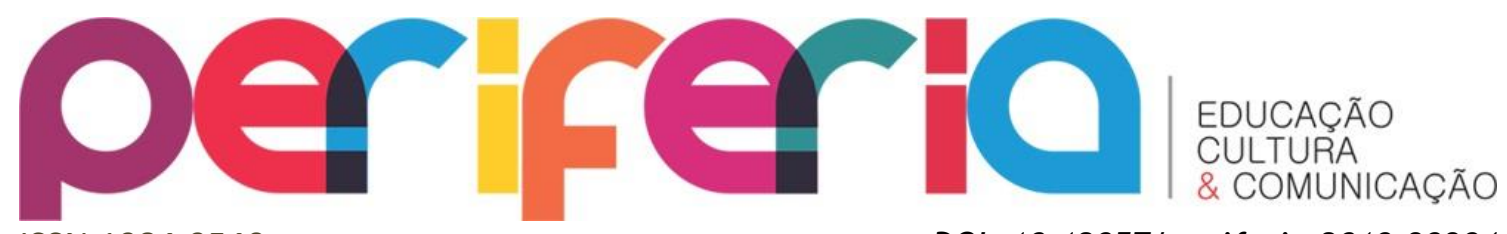

Figura 2 Infográfico metodologia

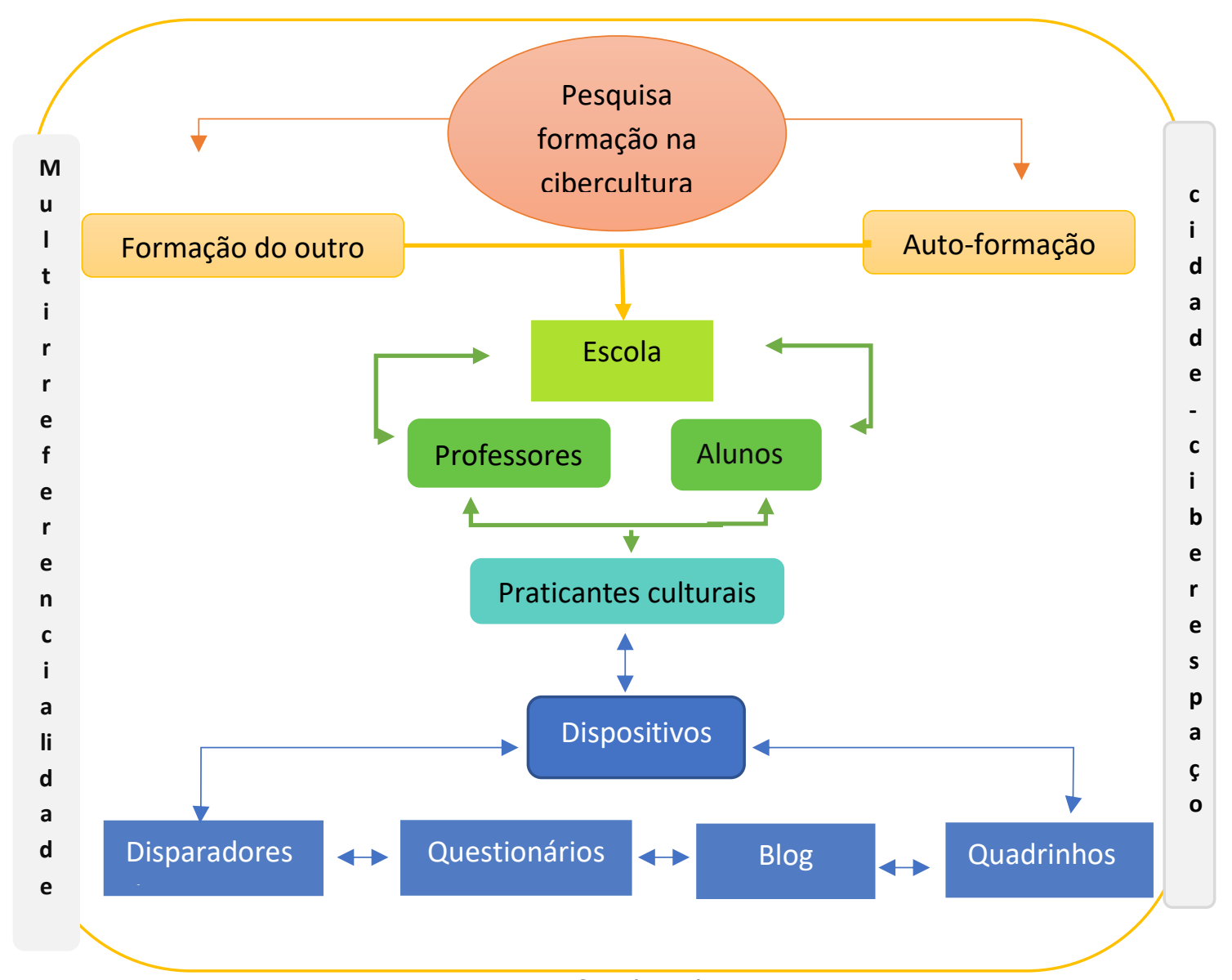

Fonte: Criado pelas autoras

O Infográfico da Figura 2 nos situa na metodologia da pesquisa-formação multirreferencial na cibercultura (SANTOS, 2014), em que pesquisador e sujeitos de pesquisa estão imbricados no processo de construção de conhecimentos. As noções de que o pesquisador é o produtor do conhecimento científico e o sujeito apenas o fornecedor de dados para a realização da pesquisa vem sendo desconstruída dentro dessa perspectiva científica.

Nesse estudo a produção do conhecimento se faz no próprio fazer reflexivo, por isso nos colocamos como sujeitos da pesquisa, implicados com a formação, na qual propomos lançar mão de dispositivos (Blog, quadrinhos, disparadores de 


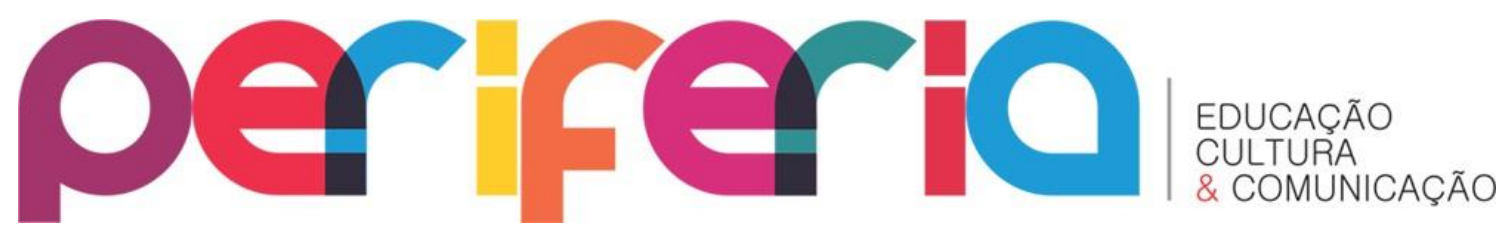

ISSN:1984-9540

DOI: 10.12957/periferia.2019.39384

conversa ${ }^{8}$ ) que possibilitem a formação do outro, sujeito da pesquisa, ao mesmo tempo em que nos percebemos em formação. Nesse cenário encontramo-nos no papel de formador e de formando, simultaneamente todos são sujeito-atoresautores 9 .

Esse processo de formação é sentido na relação tecida junto a Escola Estadual Antônio Gomes ${ }^{10}$, escolhida como campo de estudo pelos relatos e anseios que a escola demostra em querer entrelaçar saberes com a universidade em uma relação mútua de conhecimentos que potencializem a formação. Demandas esses que se confirmam e se fortalecem nas narrativas construídas em nossos encontros com a escola e nos questionários online respondidos pelos professores, como destacamos nas falas das professoras 1 e 2 .

Creio que o elemento que potencializa a docência, indubitavelmente, é a formação continua via Universidade. Sabemos que internet é um veículo de extrema relevância para o atual contexto escolar/social, portanto, temos que agregar os fatores positivos que essa ferramenta oferece ao universo escolar, uma vez que ela possui um poder de atratividade e envolvimento impactantes, qualificando cada vez mais o fazer pedagógico. (PROFESSORA 1, 2017)

Considerando a importância da formação continuada, acredito que se houver um olhar "amoroso" em relação ao espaço escolar no sentido de qualificar a prática pedagógica por meio da formação continuada, a escola e a sociedade ganharão muito com isso, entretanto, teremos que construir uma ponte entre a escola pública e a Universidade no intuito consolidar a formação continuada como sendo o elemento facilitador/qualificador da prática pedagógica. (PROFESSORA 2, 2017)

As narrativas nos mostram que a escola, como principal instituição responsável pelo letramento formal, está ciente das mudanças que a cibercultura vem

\footnotetext{
8 O uso do termo disparador de conversa é inspirado em Certeau (2012). Usamos disparadores de conversa na intenção de produzir narrativas entre nós e os alunos do $5^{\circ}$ ano, possibilitando encontrar pistas dos praticantes na relação cotidiana com as tecnologias digitais.

'Inspirados na abordagem multirreferencial (ARDOINO, 1998), usamos a noção de agente-ator-autor. 0 agente é o que executa as tarefas, o ator, reconhecido como co-produtor de sentidos executa, ao mesmo tempo em que acrescenta suas subjetividades e o autor é aquele que ressignifica, cria, funda e é genitor dos sentidos. Diante dessas noções chegamos a noção de sujeito-ator-autor, sujeito praticante cultural envolvido na pesquisa, atores como co-produtores de sentidos e autor na ideia de que os sujeitos são produtores de conhecimento, por/entre as suas redes de saberes.

${ }^{10} \mathrm{~A}$ Escola Estadual Antônio Gomes Localizada no Município de Mossoró, a instituição comporta alunos do $1^{\circ}$ ao $5^{\circ}$ ano do ensino fundamental das series iniciais, Educação de jovens e adultos e vagas para Educação Especial, atendendo em média 212 alunos.
} 


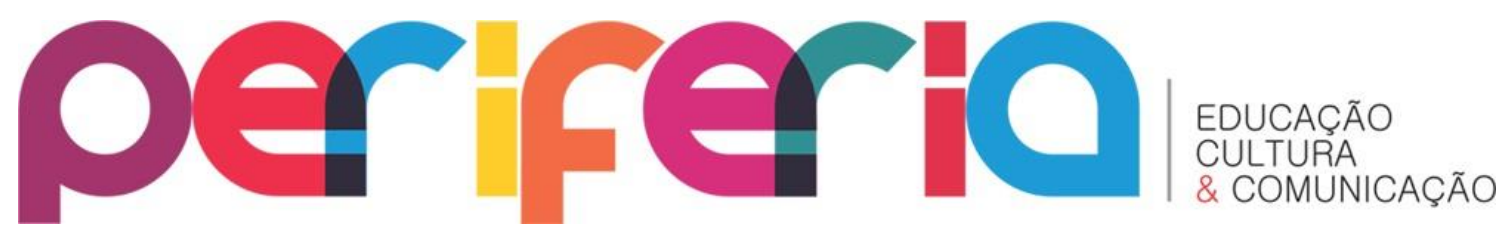

ISSN:1984-9540

DOI: $10.12957 /$ periferia.2019.39384

provocando em seu cotidiano. A multiplicidade de redes, aplicativos, softwares disponíveis em textos multimodais demandam novas formas de ensinaraprender, e a escola necessita aliar novas estratégias que atendam às necessidades formativas de uma sociedade mediada pelas tecnologias digitais. Desse modo, a escola nos dá espaço para abrir reflexões sobre esse cenário, em um diálogo com as professoras sobre as demandas que surgem nesse contexto e na mobilização de dispositivos com os alunos buscando perceber como podem potencializar os multiletramentos.

Para isso, nos colocamos dentro da escola, propondo um mergulho com todos os sentidos, como sugere Alves (2001), para que, com autonomia de quem conhece a realidade, possamos criar conhecimento junto com os sujeitos-atores-autores da pesquisa. Desse modo, iniciando esse processo de interação e envolvimento com a escola realizamos uma apresentação da nossa proposta de pesquisa. Essa apresentação se deu em parceria com a pesquisa do PIBIC e a pesquisa para Trabalho de Conclusão de Curso (TCC) ${ }^{11}$, que compartilhavam do interesse de estar na escola produzindo saberes na relação escola-universidade, mediados pelo cenário da cibercultura. Nesse processo intencionamos ouvir os sujeitos e suas percepções em relação as pesquisas. Na figura 3 apresentamos os temas das pesquisas apresentados a escola.

11 A pesquisa PIBIC tinha como tema "Multiletramentos na educação básica: diagnóstico e perspectivas", apresentando como objetivo "perceber a relação de atribuição de sentidos por alunos aos novos espaços de aprendizagem". O TCC trazia como tema "As práticas docentes e o uso das mídias no contexto da cultura digital", apresentando como objetivo "Identificar as práticas de interação com o meio digital dos professores e perceber as demandas formativas sentidas pelos docentes no desenvolvimento de suas práticas pedagógicas, no contexto da cultura digital”. 


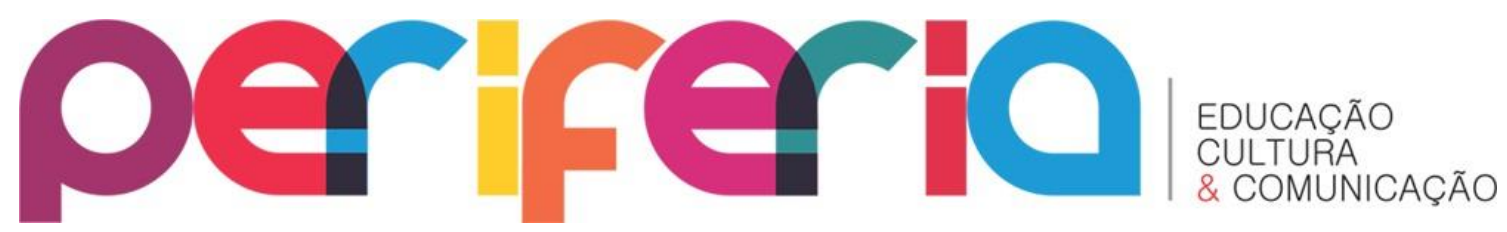

ISSN:1984-9540

DOI: $10.12957 /$ periferia.2019.39384

Figura 3 Temas de projetos de pesquisa a serem realizados na Escola

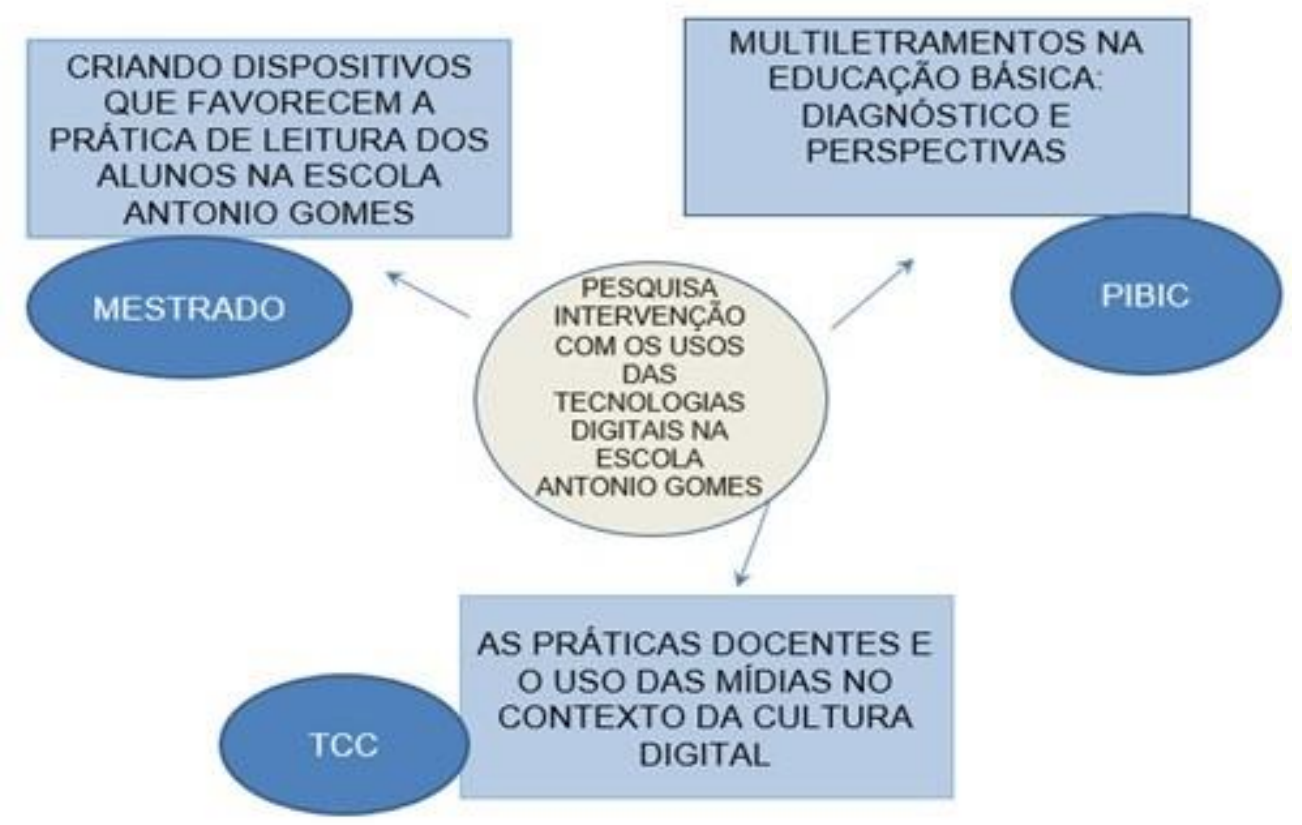

Fonte: Power point produzido pelas autoras

Buscamos ampliar nossas redes de conhecimento no diálogo com as professoras e equipe pedagógica da escola, em um momento de formação, compartilhando inquietações, dilemas e experiências da docência no contexto da cibercultura. Para isso, realizamos um questionário online em um formato que permitisse aos professores a narrativa de suas subjetividades diante as demandas da docência no contexto da cibercultura, no qual poderiam ampliar as ideias e concepções discutidas/narradas no encontro presencial.

O questionário envolveu desde questões mais amplas sobre os usos cotidianos que faziam das tecnologias digitais, às práticas e necessidades da docência na cibercultura e o cenário da leitura que perpassa a Escola Estadual Antônio Gomes. Na Figura 4, a demonstração das seções que o questionário foi organizado. 


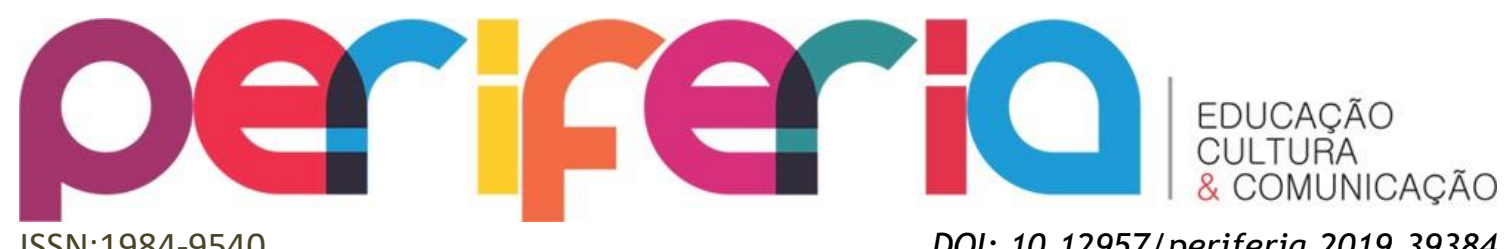

ISSN:1984-9540

DOI: $10.12957 /$ periferia.2019.39384

Figura 4 Questionário online no Google Docs

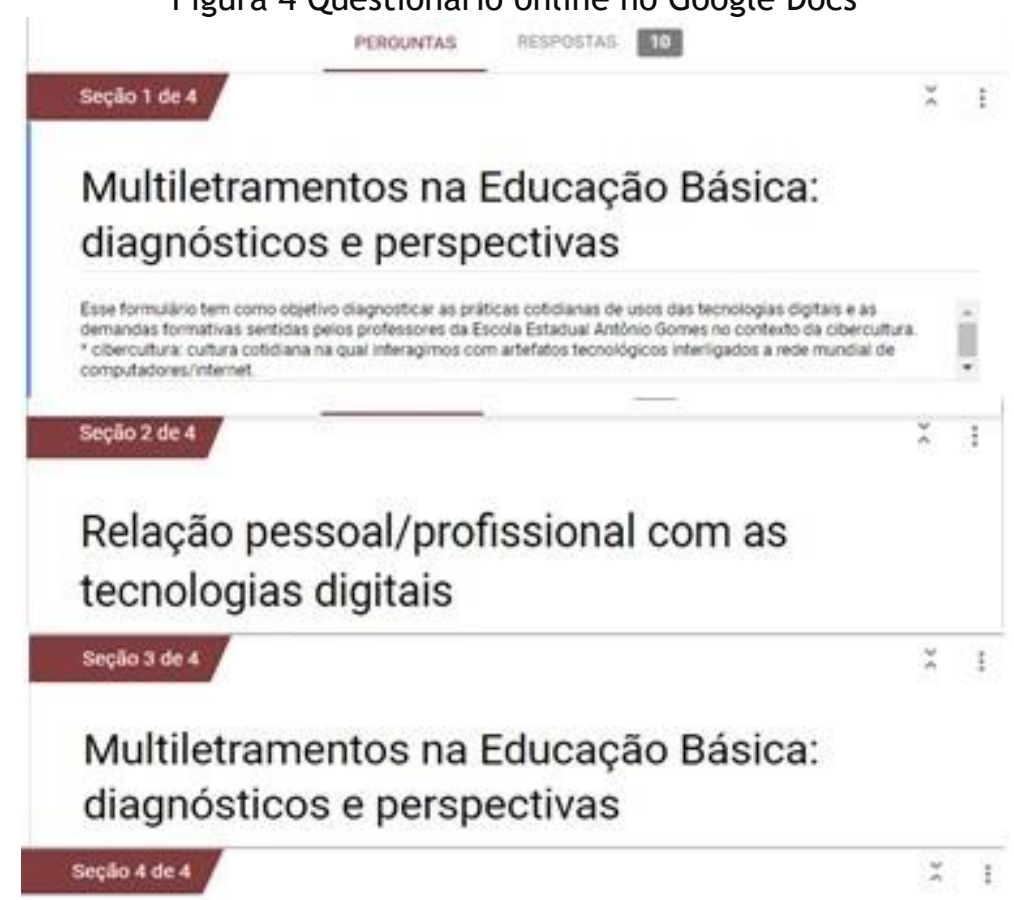

Obrigada pela grande contribuição

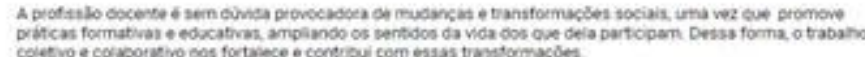

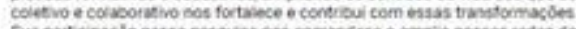

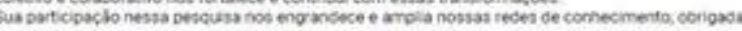

Se sentiu falta de alguma coisa no questionário narre aquí, ficaremos mais gratas ainda.

Fonte: Formulário Online (Google Docs)

As narrativas produzidas junto com os professores ampliaram nossas percepções sobre as demandas escolares no contexto da cibercultura e nos conduziram a possibilidades e estratégias de produção de conhecimento junto com os alunos. Nesse processo, dialogamos sobre as escolhas das turmas e nosso projeto foi direcionado à turma do $5^{\circ}$ ano, por serem alunos que deveriam ter uma imersão maior nas práticas de leitura e uma possível interação com as tecnologias digitais.

No entanto, para saber como os alunos lidam com a leitura nesse cenário cibercultural, realizamos um momento de interação para conhecê-los e perceber as relações cotidianas que fazem das leituras e quais redes digitais estão presentes na vida desses sujeitos. Para isso usamos vídeos como disparadores de conversa, em que os alunos assistiam e em seguida íamos mobilizando perguntas que os instigassem a 


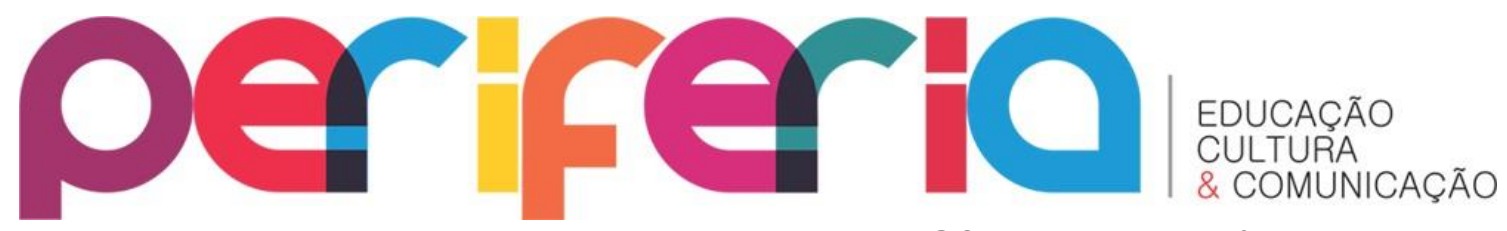

ISSN:1984-9540

DOI: $10.12957 /$ periferia.2019.39384

falar sobre as suas percepções, sentidos e atividades cotidianas relacionadas aos aspectos apresentados no vídeo. Na figura 5 , apresentamos esse momento.

Figura 5- Interação com alunos do $5^{\circ}$ ano: diálogo por meio de disparadores de conversa

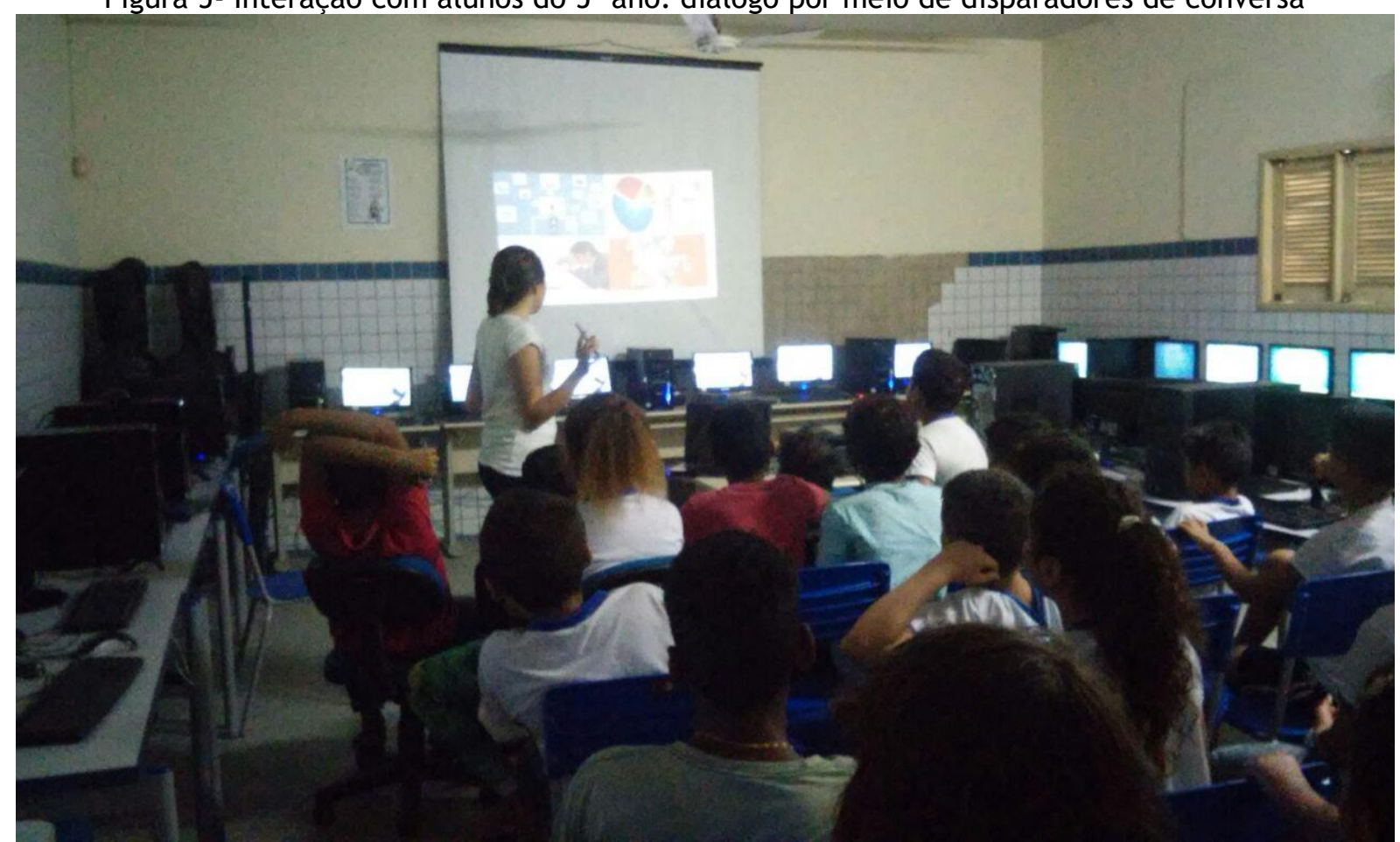

Fonte: arquivo autoras

Apresentamos dois vídeos, um intitulado "a menina que odiava livros"12", o qual usamos para dialogar sobre as práticas de leitura no cotidiano dos alunos, e outro intitulado "a evolução da tecnologia13", que usamos como disparador de diálogo sobre as tecnologias digitais e seus usos cotidianos na vida desses sujeitos. Os alunos tiveram uma boa participação nesse momento, interagiram e contribuíram com as reflexões, relataram sobre suas relações com as leituras e as redes digitais que interagem cotidianamente. Ainda em uma perspectiva diagnóstica interativaformativa, criamos um questionário online para que os alunos especificassem alguns aspectos que consideramos fundamentais para o prosseguimento da pesquisa, como o acesso à internet, as redes sociais que estão

\footnotetext{
12 https: / / www.youtube.com/watch?v=geQl2cZxR7Q

13 https://www.youtube.com/watch?v=tcLLTsP3wlo
} 


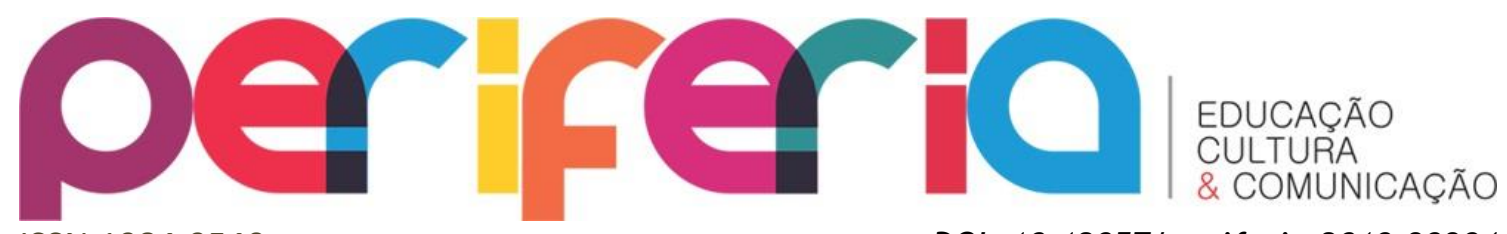

ISSN:1984-9540

DOI: 10.12957/periferia.2019.39384

inseridos, as leituras que mais gostam de fazer, os tipos de livros que leem etc. 0 questionário foi criado no site survio.com, que permite que os participantes interajam e respondam as questões sem a obrigação de um cadastro no site. Na figura 6 mostramos a página inicial do questionário.

Figura 6 Questionário online com os alunos

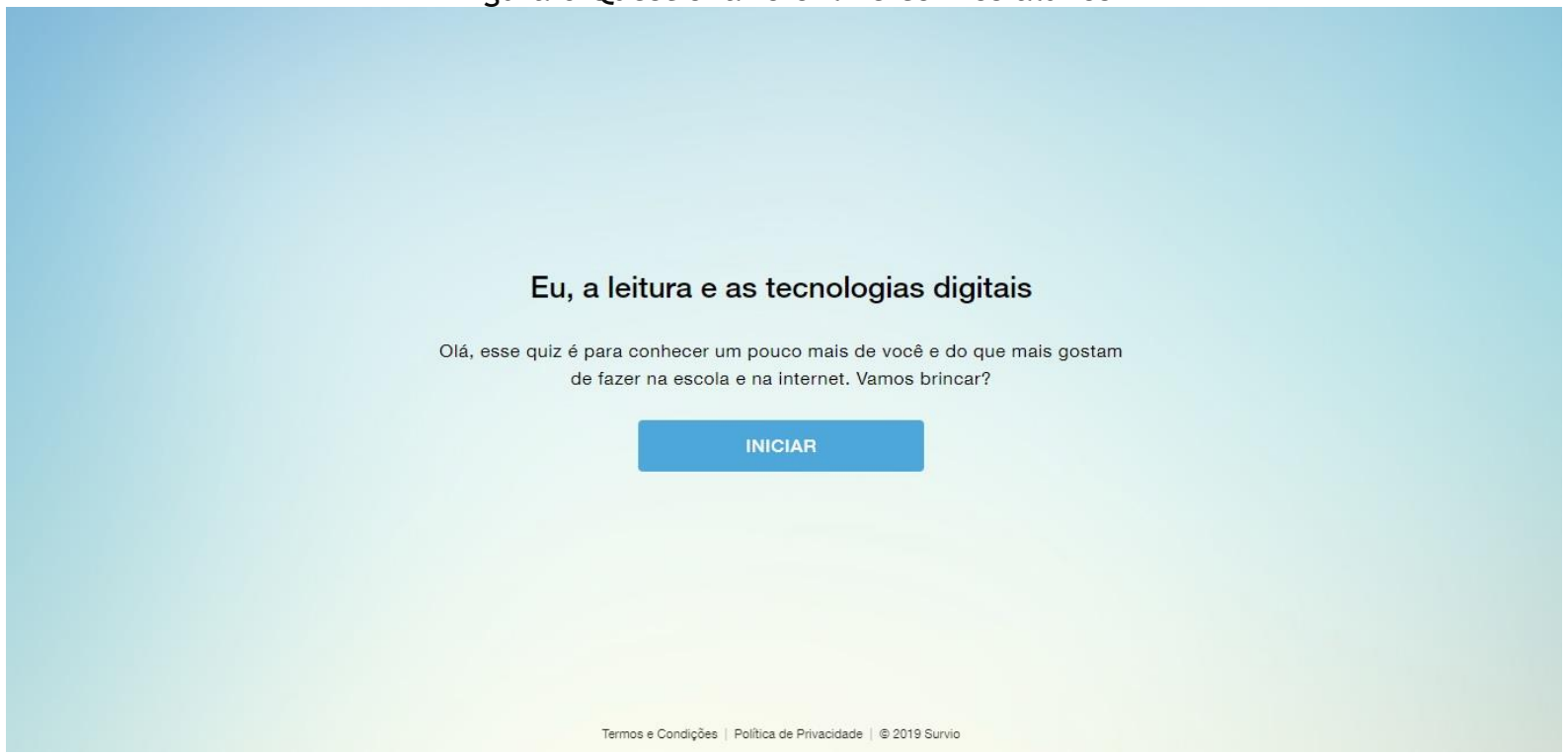

Fonte: https://www.survio.com/survey/d/A9Y7A2P1T2Q5S2H5Q

Por meio desses momentos de interação com os alunos foi perceptível que a maior parte deles estão conectados aos ciberespaços. De 22 alunos apenas 4 dizem não ter internet em casa, mas relatam que acessam a internet em lanhouses e/ou locadoras. Os alunos apresentam nas respostas que estão conectados as redes digitais, eles navegam nas redes sociais, jogos online e vídeos no youtube, sendo as redes mais citados no diálogo e respostas no questionário. Como apresentamos na figura 7. 


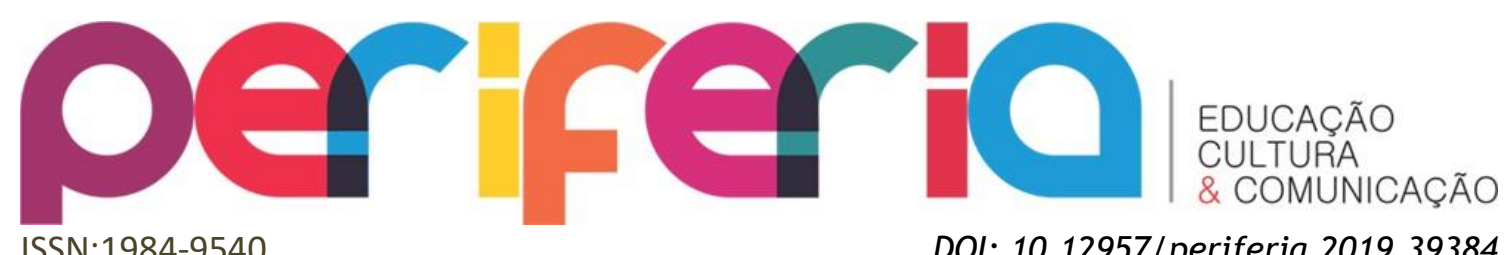

ISSN:1984-9540

DOI: $10.12957 /$ periferia.2019.39384

Figura 7 Respostas dos alunos questionário online

\begin{tabular}{|c|c|c|c|}
\hline 80 que você mais $g$ & de fazer na interne & & \\
\hline joga $(3 x)$ & yotube facebook & yuotube & jogar \\
\hline assistri os iotuberes & jogos $(2 x)$ & JOGAR & \multirow{2}{*}{$\begin{array}{l}\text { conversar com minhas } \\
\text { amigas no whaatsap }\end{array}$} \\
\hline JOGA & YOUTUDE & You tube & \\
\hline ESCUTAR FANQUE & musica & ASSISTIR & \multirow{2}{*}{$\begin{array}{l}\text { WHATSAPP } \\
\text { gogar }\end{array}$} \\
\hline $\begin{array}{l}\text { JOGAR NO CELULA } \\
\text { SUBWAY SURFERS }\end{array}$ & assistir no youtube & JOGAS DE CELOLA & \\
\hline
\end{tabular}

Fonte: https://my.survio.com/C2Q101J8X5S1G2E9B4I5/data/index

Mediante as respostas sentimos que os alunos que estão nas escolas hoje vivem a cultura do digital em rede, conectados aos ciberespaços interagem pelo universo plural de informações construindo saberes que se diferem das gerações que os antecederam. Quando perguntamos se eles gostam de acessar internet a resposta é imediata “claro! Quem não gosta né?”. Para eles estar nas redes é como se fosse uma condição de vida, “como seria possível alguém viver sem internet?”. Estamos lidando com uma geração outra, que manipula várias informações ao mesmo tempo, que não interagem, vivem e percebem o mundo da mesma forma que seus antepassados.

Para Serres (2013) essa é a geração Polegarzinha, que apenas com o uso dos polegares navega pelos espaços não lineares da internet, habitam o virtual. Não tem mais as mesmas expectativas de vida, leem e escrevem de outras formas, em outras redes que despertam outras habilidades e outras maneiras de viver. Esses sujeitos veem na internet possibilidades de interação, produção de conhecimento e expectativas de empregos, como podemos ver no relato do aluno 1, "meu sonho é ser youtuber como Whindersson Nunes e Felipe Neto ${ }^{14}$, ficar rico fazendo vídeo, trabalhando em casa, é bom demais”. Para esses sujeitos a internet é espaçotempo de vida.

\footnotetext{
${ }^{14}$ Estão entre os youtubers mais famosos do Brasil, os seus perfis têm entre 13 a 20 milhões de inscritos. São conhecidos por seus canais de comedias que atraem e envolvem o público, os deixando no ranking dos maiores youtubers do brasil.
} 


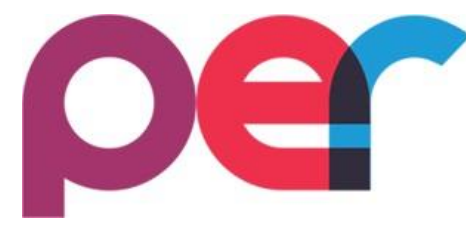

ISSN:1984-9540

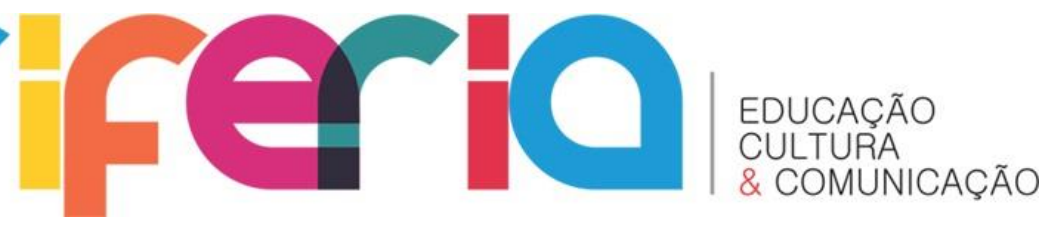

DOI: $10.12957 /$ periferia.2019.39384

Precisamos refletir sobre essas demandas e a maneira com a qual lidamos com esse cenário, tecendo um posicionamento crítico sobre como a tecnologia reflete em nossas vidas e como nós, enquanto praticantes culturais, lidamos com ela. Trata-se de uma realidade de multiculturas, multilinguagens, multiletramentos que se entrelaçam e necessitam ser discutidos.

Nesse sentido, temos que pensar sobre as potencias dessa cultura para a aprendizagem entre os jovens, pois, não podemos ignorar a grafia das palavras redigidas pelos alunos no questionário apresentado na Figura 7. Como melhorar a competência linguística dos alunos? Na linguagem cibercultural não devemos priorizar a norma culta na elaboração textual? Como usar esse universo motivador das tecnologias digitais em prol de competências de leitura e escrita?

Nesse veio, nos colocamos dentro no campo de produção de conhecimento, junto aos sujeitos-atores-autores da pesquisa, em relações tecidas com professores e alunos desejantespraticantes da/na cibercultura, em uma perspectiva diagnóstica para que pensássemos em como a pesquisa seria desenvolvida, pois inspiradas na concepção da bricolagem em Kincheloe e Berry (2007), adotamos uma postura ativa, que rejeita os roteiros prontos e preestabelecidos, e criamos os nossos próprios processos de investigação de acordo com as demandas e realidades vividas.

\section{Dispositivo de leitura: o aplicativo pixton}

A aprendizagem, enquanto devir, se dá por meio dos sentidos que atribuímos aos saberesfazeres, sempre referenciados nas nossas práticas e vivências cotidianas (MACEDO, 2010). Nos colocando como negociadores metodológicos que respeitam as demandas a serem cumpridas e a realidade dos sujeitos e do espaço de pesquisa (KINCHELOE, 2007). Dessa forma, apresentamos um projeto com atividades didáticas a serem realizadas na escola, com o objetivo de mobilizar dispositivos de leitura que potencializassem os multiletramentos dos alunos, envolvendo a cultura dos sujeitos, as redes que estão inseridos, trazendo as demandas sentidaspercebidas no diálogo com a escola e com os alunos. 


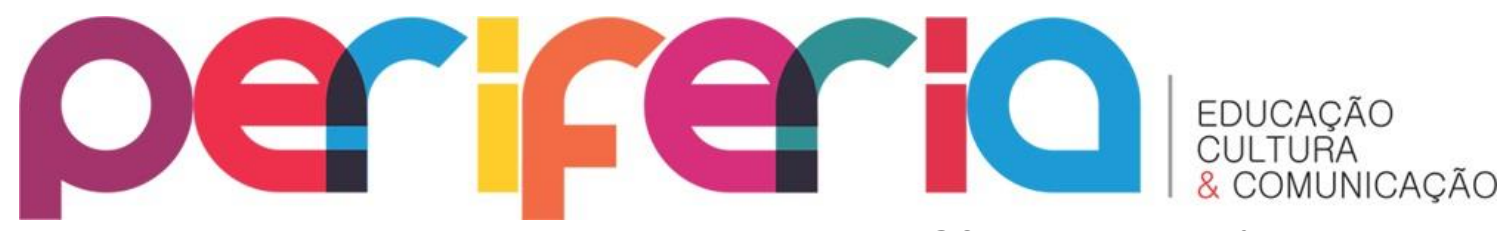

ISSN:1984-9540

DOI: 10.12957/periferia.2019.39384

Nesse projeto, trazemos o blog como interface de produção de conhecimento em rede, espaçotempo de leitura e escrita nas telas eletrônicas, ampliando a interação dos sujeitos sob os múltiplos letramentos disponíveis no ciberespaço. Através desse dispositivo pudemos ampliar o envolvimento e o desejo atribuído ao que estávamos vivendo. Ao propormos que os alunos construíssem o blog em parceira conosco, possibilitamos que eles se percebessem implicados na própria pesquisa. Para isso, realizamos um momento de interação para que todos conhecessem a estrutura e a criação de um blog para que assim pudéssemos vivenciar essa experiência. Na figura 8 apresentamos o blog criado junto com os alunos.

Figura 8 Blog viajando pelo mundo da leitura

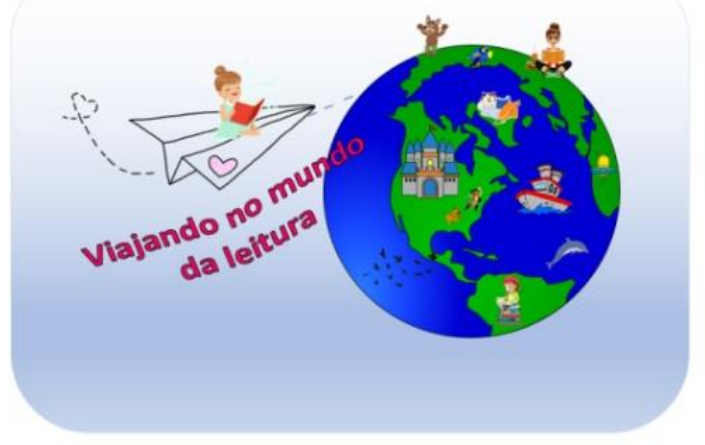

\section{VIAJANDO NO MUNDO DA LEITURA}

ESSE BLOG FOI CRIADO COM A TURMA DO $5^{\circ}$ ANO PARA COMPARTILHAR E INTERAGIR NAS REDES. AQUi COMPARTILHAREMOS AS NOSSAS

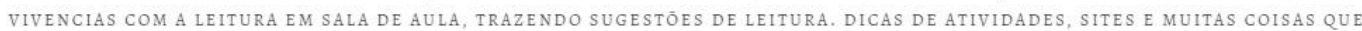
CONSTRUIREMOS JUNTOS.

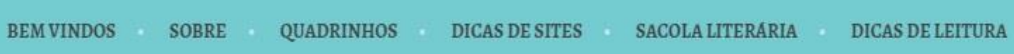

Fonte: https://viajandoonomundodaleitura.wordpress.com/ Produzido com os alunos.

Os alunos se mostravam atentos e envolvidos nesse momento, no qual apresentamos as sugestões de títulos e imagens, criadas previamente junto à professora da sala campo de pesquisa, para que, posteriormente, eles escolhessem quais seriam utilizados como nome e imagem de capa do blog. Em seguida fomos criando junto com eles o blog, projetamos o site e fomos construindo e preenchendo 


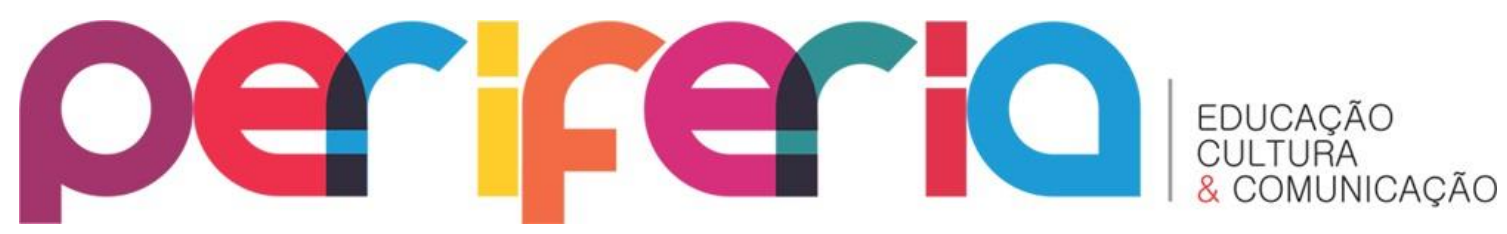

ISSN:1984-9540

DOI: 10.12957/periferia.2019.39384

os dados necessários para a criação da interface, cada aluno ia colaborando com uma parte até que concluíssemos a criação.

Buscamos envolver os alunos nesse processo pois compreendemos que quando nos sentimos como parte do processo de formação, nos vendo como co-produtores de sentidos, nos encontramos com a autorização (ARDOINO 1998), um processo de nos tornarmos ator-autores de nós mesmos, sujeitos pensantes e produtores de conhecimento. A aprendizagem enquanto processo relacional do sujeito com o mundo, com o outro e consigo mesmo, é estimulada pelo desejo e envolvimento de quem aprende com o meio que está inserido, portanto, a autorização se firma nessa rede como ação de um sujeito transformando-se ao transformar o mundo (ARDOINO, 1998).

Em um cenário multimodal os alunos precisam desenvolver capacidades de se tornarem seus próprios co-autores, se vendo de dentro do processo de formação. Por isso, na mobilização dos dispositivos, buscamos envolver as redes que os alunos estão inseridos e os dispositivos que fazem parte de seu cotidiano. Assim, trazemos os contos e quadrinhos como gêneros textuais centrais a serem trabalhados nesse processo, visto que estão entre os mais citados na lista de leituras dos alunos. Para organização dos dispositivos mobilizados apresentamos uma sequência didática a ser realizada com os alunos do $5^{\circ}$ ano na escola, como apresentamos no quadro 1 . 


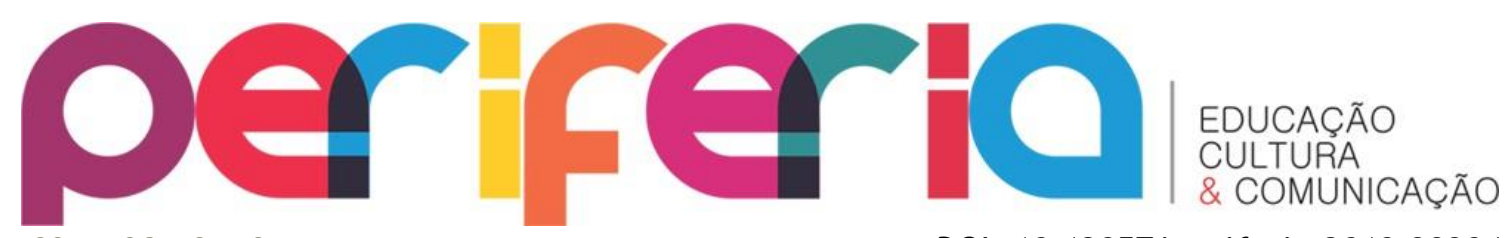

ISSN:1984-9540

Quadro 1 Sequência didática

Tema: "Quem reconta um conto aumenta um ponto"

Objetivos:

- Aperfeiçoar as práticas de leitura

- Recriar conto a partir da contação de história

- Conhecer aplicativos de criação de quadrinhos online

- Criar quadrinhos a partir de reconto

- Compartilhar no blog as produções

- Interagir com multiletramentos

Momento 1 - Hora da história

Na sala de aula realizamos um momento de contação de história para os alunos por meio da leitura do livro "Brinca, menino" da autora Leticia Wierzchowsk.

Roda de conversa sobre as compreensões e reflexões sobre o conto e suas relações com cotidiano.

Momento 2: Recontando o canto

Se você fosse o autor desse texto, o que mudaria? Reescreva o conto contanto como seria sua versão da história.

Momento 3 - Transformando o reconto em quadrinhos

- Apresentação de powerpoint com introdução do que é quadrinhos. Dialogando com os alunos sobre a atividade a ser realizada, na qual eles irão pegar o reconto que criaram e o transformarão em quadrinhos, no computador, por meio do aplicativo pixton.

- Apresentação do aplicativo de criação de quadrinhos online (PIXTON). Com um passo a passo de como acessar o site, se conectar a ele e criar os quadrinhos.

Momento 4 - Entrando em ação

Tendo conhecido o aplicativo e suas funções básicas, os alunos criarão seus quadrinhos, usando sua imaginação criarão os personagens, o cenário e o enredo da história.

Momento 5- Compartilhando saberes

Os alunos compartilharão as suas produções no blog.

Fonte: Produzida pelas autoras

$\mathrm{Na}$ realização dessas atividades buscamos perceber como os alunos lidam com a leitura em seu cotidiano, seja ela nos livros e/ou nas telas eletrônicas, por meio do uso de dispositivos que envolvam e potencializem os multiletramentos. Ressaltamos que trabalhar com os multiletramentos não necessariamente vai envolver as tecnologias digitais, como coloca Rojo (2012), mas nesse caso envolvera, visto que propomos uma metodologia que se tece a partir das redes que os sujeitos estão imersos e eles vivem a cibercultura, um cenário plural de letramentos e 


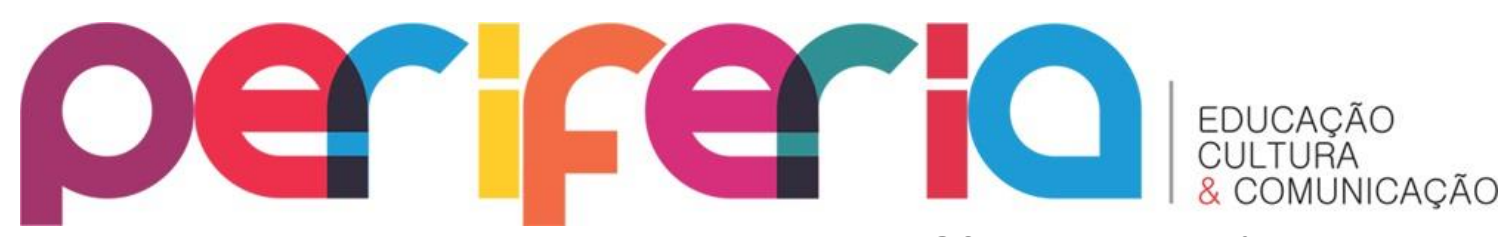

ISSN:1984-9540

DOI: 10.12957/periferia.2019.39384

informações. Por isso mobilizamos dispositivos que envolvam os multiletramentos desses alunos, por meio da leitura e escrita de textos no papel e nas telas eletrônicas.

Realizamos uma contação de história por meio da leitura do livro "Brinca, menino" de Leticia Wierzchowsk, acreditando que a leitura enquanto prática fundamental na formação do sujeito, precisa ser estimulada, e a escola enquanto espaço formativo tem essa responsabilidade. A leitura realizada foi ao encontro da realidade dos sujeitos, para que estabelecessem sentido e relações com suas vivências cotidianas. Desse modo, nessa atividade, buscamos um texto que nos possibilitasse refletir sobre o cenário da cibercultura e aspectos cotidianos vividos/percebidos pelos alunos. Na figura 9 nosso momento de contação de história.

Figura 9 Momento de contação de história com os alunos

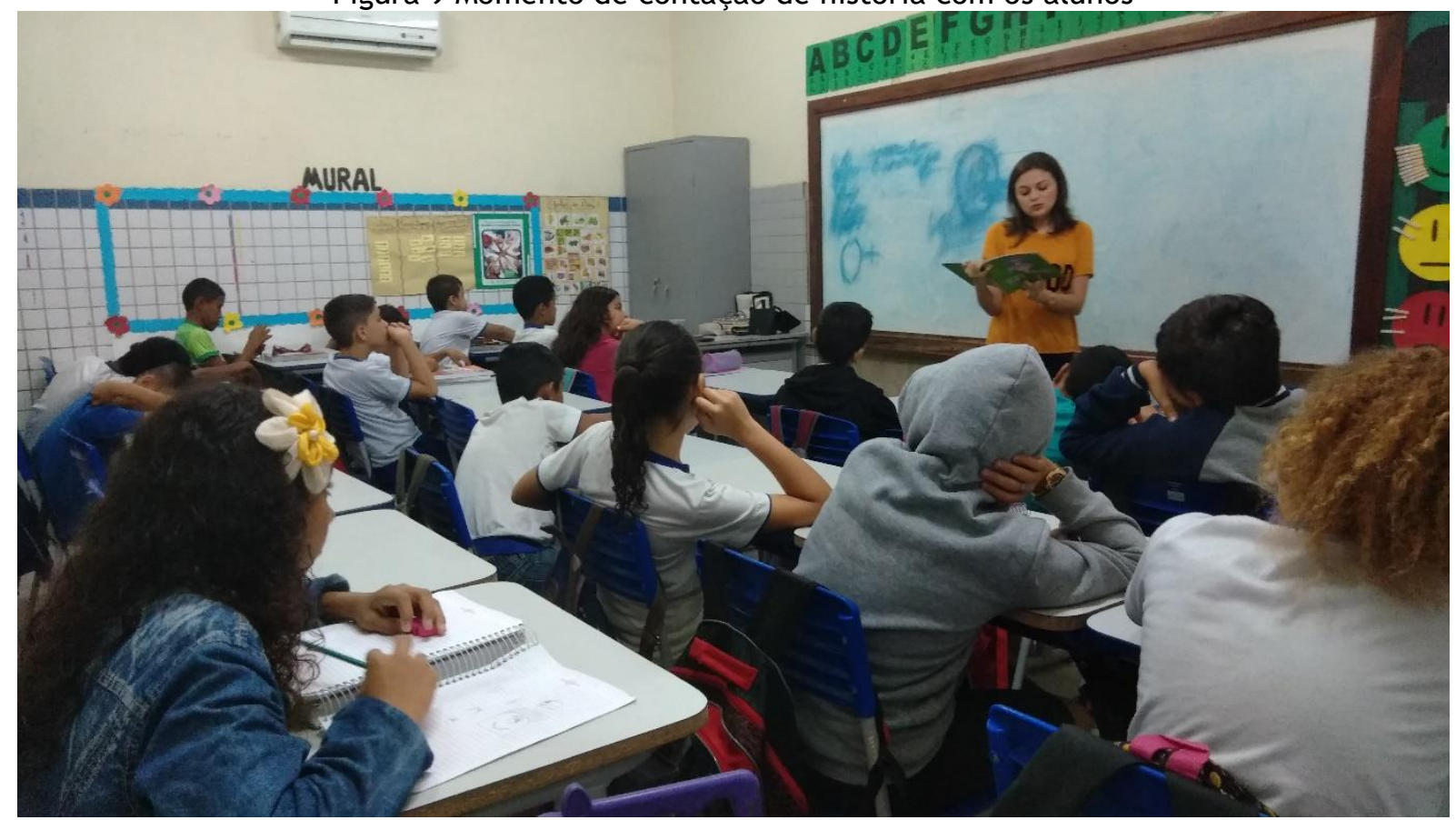

Fonte: Arquivo autoras

Em uma roda de conversa sobre as percepções acerca da leitura, refletimos sobre as inquietações levantadas e propomos que os alunos recontassem o conto modificando o que eles, caso fossem os autores do texto, contariam diferente. Nesse momento, pudemos interagir mais com os alunos, observando as formas de escrita de cada um, as dificuldades e facilidades com o reconto. 


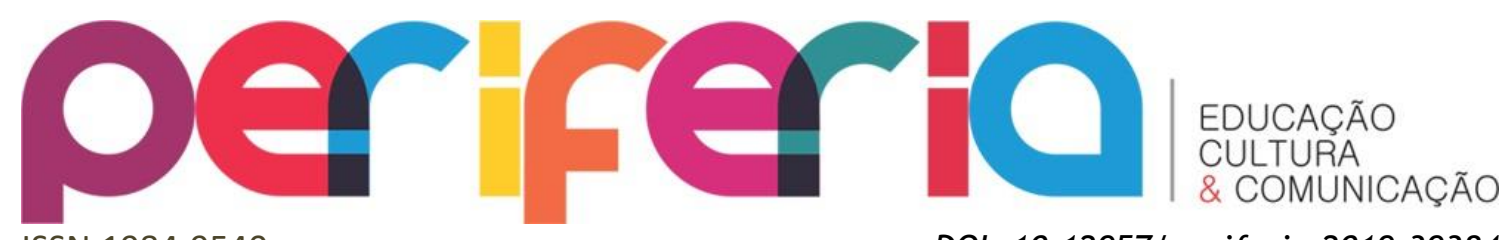

ISSN:1984-9540

DOI: $10.12957 /$ periferia.2019.39384

Nessa produção observamos que estamos lidando com um público com diferentes habilidades em relações a leitura e escrita. No processo de alfabetização, no sentido de decodificação alfabética e habilidades de compreensão e interpretação textual, há maior dificuldade. Observamos a dificuldade de organização das ideias, da escrita das palavras e da produção textual. Já outros alunos tinham facilidade e coerência na escrita do texto, vemos isso na figura 10 , nas produções de dois alunos.

Figura 10 Produção textual feita pelos alunos do $5^{\circ}$ ano do Ensino Fundamental

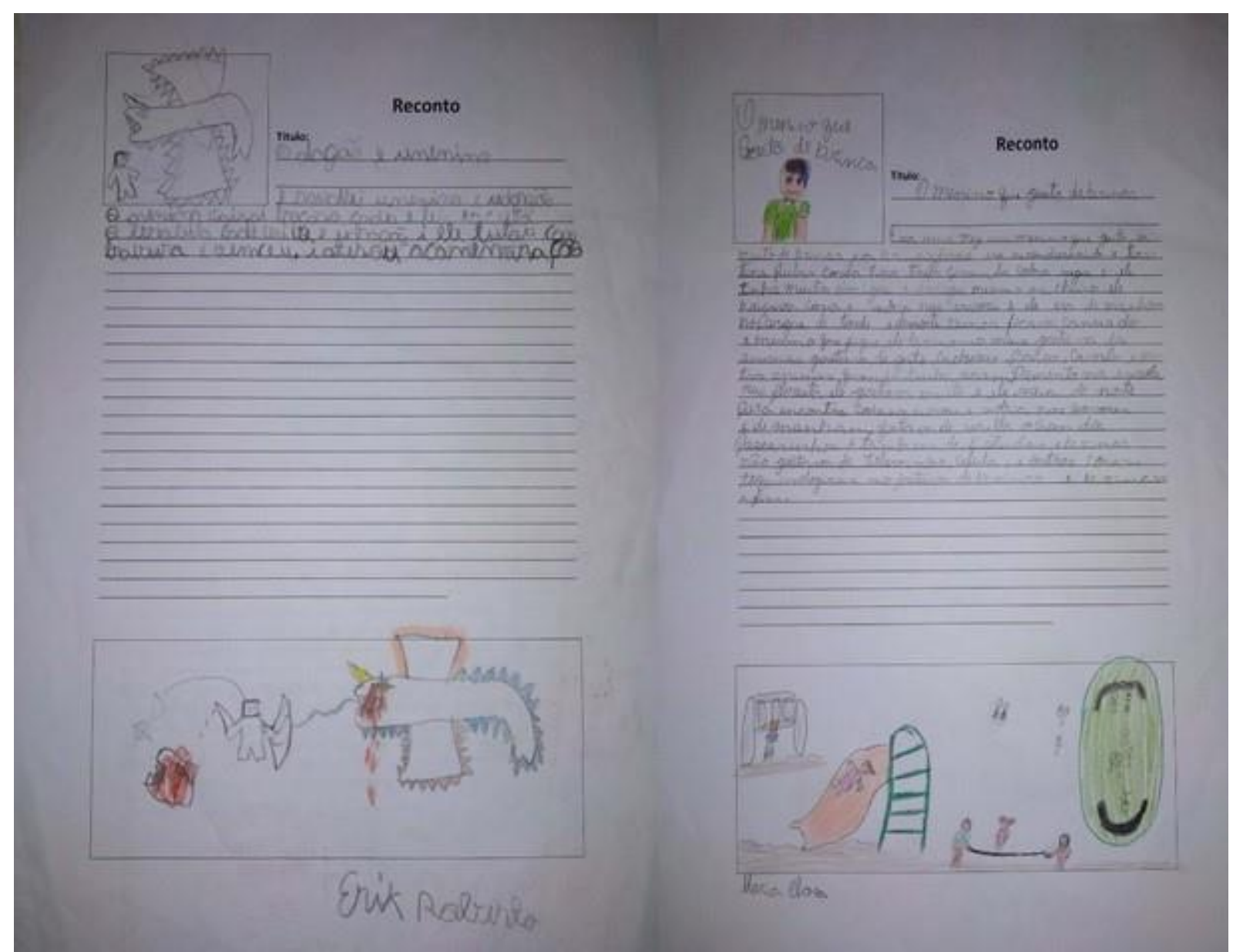

Fonte: arquivo autoras

Ver essas produções nos faz refletir sobre como a leitura é sentida/vivida/praticada por esses alunos? Como os alunos, mesmo com dificuldades de leitura, conseguem navegar e interagir no/com os ciberespaços? Esses são dilemas que vão nos inquietando e nos envolvendo com a pesquisa. Em busca de perceber 


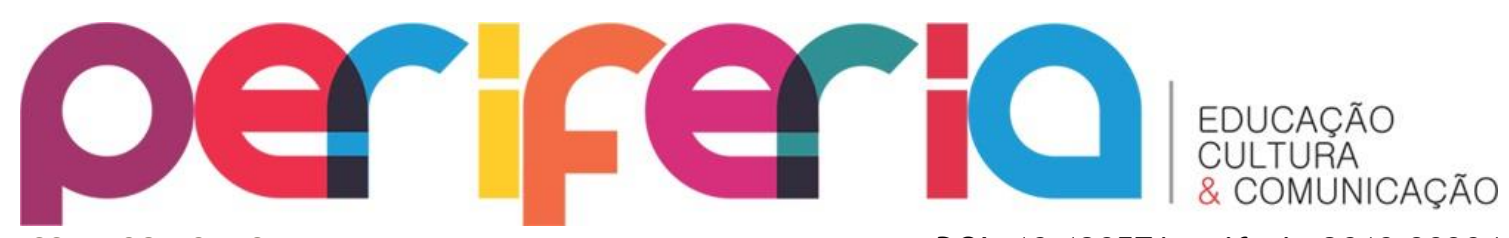

ISSN:1984-9540

DOI: $10.12957 /$ periferia.2019.39384

como se dá a relação desses sujeitos com as tecnologias digitais, propomos que eles transformassem esses recontos em histórias em quadrinhos através do site pixton.com. Em meio a essa produção buscamos refletir acerca desses dilemas que nos inquietam.

A produção dos quadrinhos, no site pixton, realizada na sala de informática, foi um momento fundamental para aprofundarmos as reflexões sobre essas questões, pois transitamos entre a produção escrita do papel para a tela do computador, em realidades completamente distintas, em que os alunos lidavam com dispositivos diferentes nas produções textuais. Nessa atividade pudemos perceber como os alunos interagem com os computadores, se a escrita muda, quais estratégias os que tem dificuldade na leitura e escrita usam para estar nesses espaços. Na figura 11, apresentamos a página inicial do site Pixton.

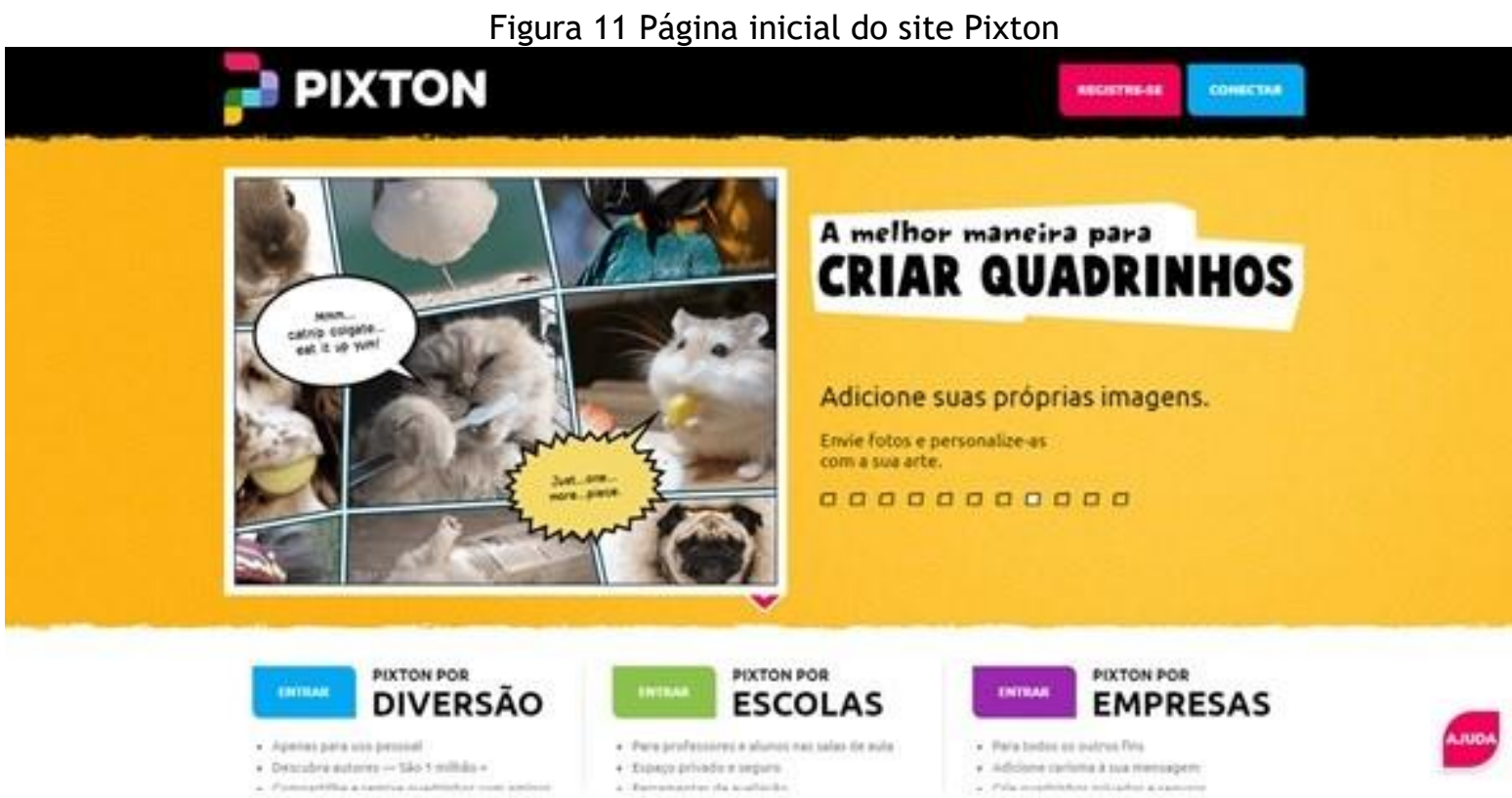

Fonte: https://www.pixton.com/br/

Como esse site não era conhecido pelos alunos, demos início a atividade com sua apresentação, mostrando como acessar, criar e compartilhar os quadrinhos. Criamos um passo-a-passo que simultaneamente íamos mostrando como produzir e os alunos iam realizando no site. Após conhecerem o Pixton e algumas de suas funções, dividimos os alunos em duplas e pedimos que escolhessem um dos recontos para criarem os quadrinhos. Os alunos interagiram bem com esse espaço. 0 fato de 


\section{oer
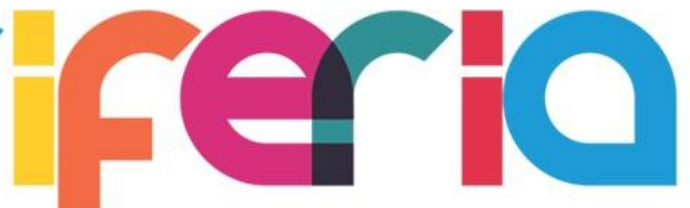 \\ EDUCAÇÃO \\ CULTURA \\ \& COMUNICAÇÃO}

ISSN:1984-9540

DOI: 10.12957/periferia.2019.39384

poderem criar o seu personagem, escolher suas características, o cenário que se passava a história os envolveu e motivou na produção. Nas figuras 12 e 13 trazemos algumas das produções dos alunos no aplicativo Pixton.

Figura 12 Quadrinhos produzidos por alunos no PIXTON

\section{O menino e suas brincadeiras}

(9) Friday September 21, 2018 Arcuivedo em Comécia
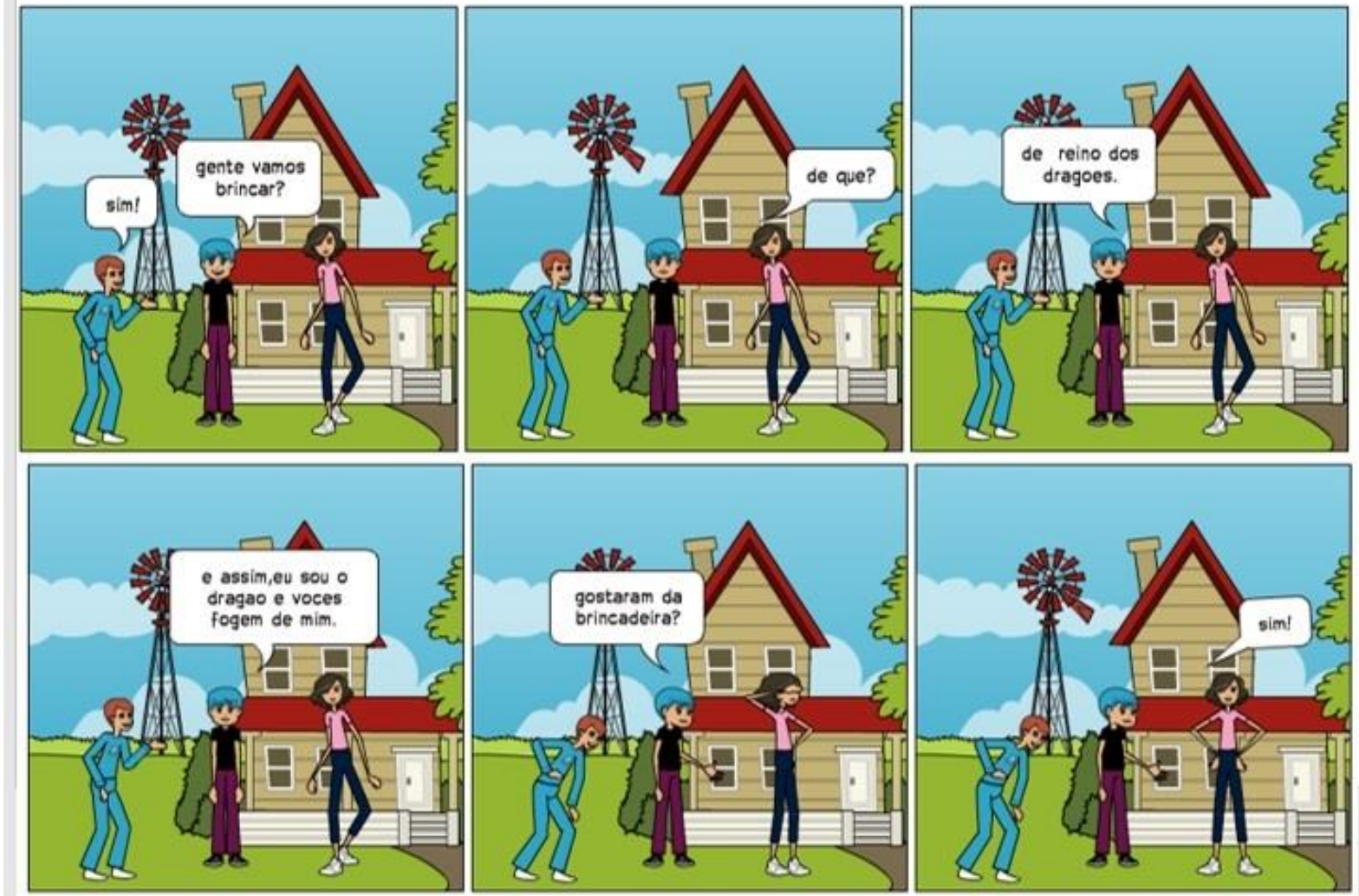

Fonte: https://Pixton.com/hq:hvvm9uwo 


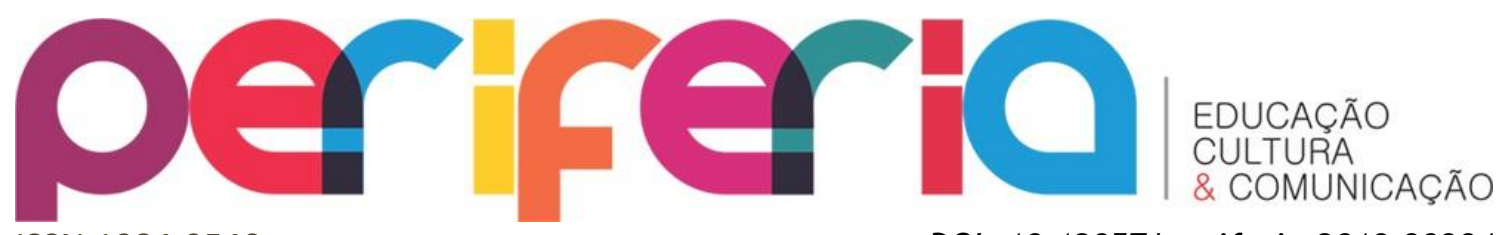

ISSN:1984-9540

DOI: $10.12957 /$ periferia.2019.39384

Figura 13 Quadrinhos produzidos por alunos no PIXTON

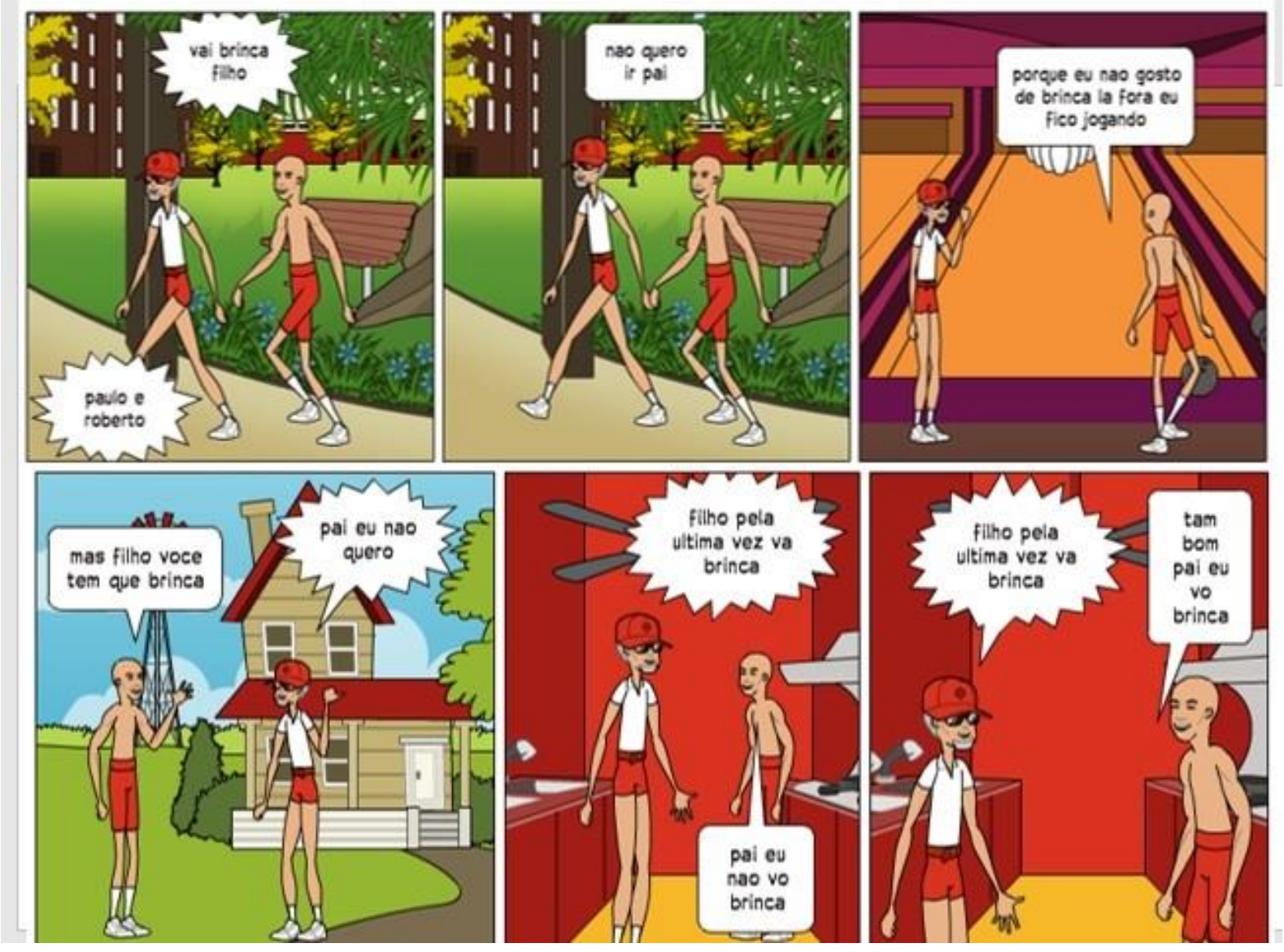

Fonte: https://www.pixton.com/br/comic/qrueivqi

0 processo de produção textual requer mobilizar várias competências linguísticas, uma vez que, além da grafia das palavras, a coesão, a coerência, a sequência lógica do texto em relação às imagens selecionadas e a forma de sistematização de um gênero literário específico, o quadrinho precisa estar em harmonia. Além dessas mobilizações, a atividade sugeria um reconto com o texto anteriormente produzido.

Observando as atividades dos alunos percebemos que eles conseguiram produzir seus quadrinhos, criaram seus personagens e uma história. No entanto, algumas das histórias não se aproximaram do reconto que produziram. A impressão que tivemos é que ao disporem de outras possibilidades gráficas, ou seja, outras narrativas em imagens, os alunos se autorizaram a criar outras ideias cheia de sentidos para eles, como é o caso da Figura 13 em que a criança lança mão de uma 


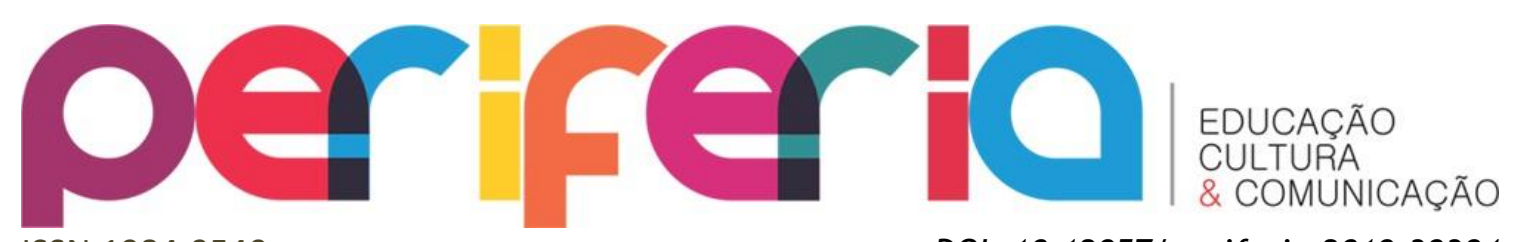

ISSN:1984-9540

DOI: $10.12957 /$ periferia.2019.39384

realidade bem presente em nosso cotidiano, os pais implorando para que o filho "brinque", entendendo como brincadeira o estar com o outro, o correr livremente, o interagir com a natureza.

Percebemos que a dificuldade de escrita dos textos permanecia, mas no aplicativo os alunos iam observando que as palavras escritas erradas eram sublinhadas de vermelho e iam tentando concerta-las. 0 que diminuiu os erros e facilitou a leitura e compreensão da história. Os dispositivos disponibilizados na internet facilitam a vida dos sujeitos que não sabem ler, as buscas por comando de voz, a comunicação por chamadas de áudio e vídeo, o uso de imagens e emojis nas mensagens vão dando possibilidades outras de leitura e escrita.

Outro aspecto que consideramos relevante na atividade realizada é a interação com aplicativos que potencializam a aprendizagem de competências linguísticas por meio da mediação e da intencionalidade formativa. Em Ribeiro (2015), percebemos a contribuição em criarmos currículos que favoreça o letramento digital docente e discente em uma perspectiva em devir da formação do autor cidadão na cibercultura, ou seja, para a autora a formação do ciberautorcidadão "nos remete à cidadania que se constrói na relação cidadeciberespaço, em espaçotempos de aprendizagens plurais nos quais nos autorizamos como autores que pensam e fazem currículos em seus cotidianos, enredados pelos/nos conteúdos formais de ensino, relações sociais, manifestações culturais" [...] (p.152 ).

Destacamos na noção do ciberautorcidadão, a importância da escola e do professor na mediação às escolhas, na busca pela formação autoral situada na cultura cotidiana dos alunos e na criação de dispositivos que ampliem os multiletramentos. Nesse cenário, a escola é lócus privilegiado de inclusão social e de produção de uma sala de aula inforrica ${ }^{15}$ (SILVA, 2003).

A produção textual por meio do aplicativo impulsionou os alunos a interação com os multiletramentos, ampliando suas redes de informação e conhecimento cotidianos e escolares. Em meio a esse processo é perceptível que quando deixamos

\footnotetext{
${ }^{15}$ Referimo-nos a ideia de uma sala de aula que o professor aproveita ao máximo o potencial das tecnologias digitais em função de aprendizagens plurais, em especial, no caso da pesquisa em discussão, das práticas de interação com a leitura e a escrita em textos multimoldais.
} 


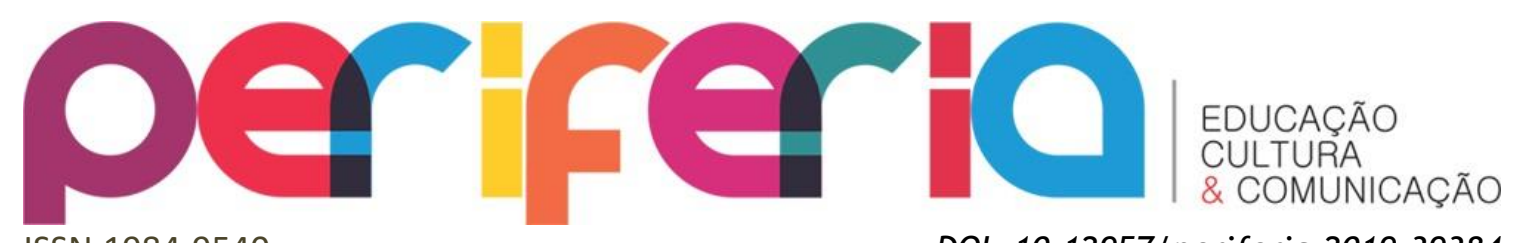

ISSN:1984-9540

DOI: 10.12957/periferia.2019.39384

os alunos mais livres nos computadores para produzirem suas histórias eles se entregaram mais, se envolveram mais, o que nos leva a inferirmos que eles estão se sentindo mais autores de seus trabalhos, produzindo-os e compartilhando nas redes.

Estamos falando de um novo tipo de leitor, o ciberleitor que ler nas telas e transcende a noção de leitor de textos escritos para o leitor/produtor da imagem, áudios, hipertexto, vídeos, memes e tantas outras práticas de multiletramentos das quais participa como praticante dessa cultura. Um leitor que amplia sua visões nas telas para um universo mais amplo de textos, com outros letramentos, que cria vídeos, que navega pelos espaços não lineares do ciberespaços e criam estratégias de interação e comunicação, em uma leitura que não se fecha na decodificação pura da palavra, mas que se estende a leitura e compreensão do mundo (FREIRE, 1989).

Desse modo, por entre essas vivências chegamos ao entendimento de que a ciberleitura na educação básica é uma realidade possível, em que professores e alunos podem criar possibilidades formativas no dentro e fora das redes digitais, com rigor e implicação aos objetivos que pretendem alcançar. 0 que cabe a nós compreender é que precisamos de novas propostas curriculares que envolvam essas demandas e que, desde a formação inicial do professor, sejam discutidos e praticados currículos em que as tecnologias digitais estejam presentes.

\section{CONCLUINDO O TEXTO}

Iniciamos nossa tessitura textual afirmando que é necessário compreender que para realizar uma pesquisa-formação na cibercultura é preciso estarmos implicados, interagir com os sujeitos, nos envolvermos com/em suas redes de conhecimento produzidas na relação cidadeciberespaços, criarmos estratégias de aproximação para conhecermos e estarmos juntos aos sujeitos nesse processo de formação. Com essa inspiração epistemológica e metodológica caminhamos no estudo com o propósito de percebermos as possibilidades da formação do ciberleitor na educação básica. Como resultados, mesmo que provisório, temos que: 


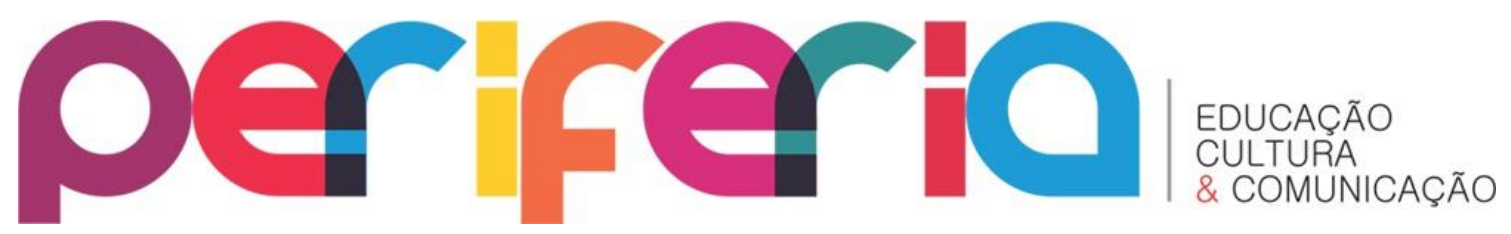

ISSN:1984-9540

DOI: $10.12957 /$ periferia.2019.39384

Os professores que protagonizam o ensino na escola pública campo de pesquisa são sujeitosdesejantes de saberesfazeres na cibercultura e consideram a formação inicial e continuada como lócus de uma formação que possibilite a construção de competências para a criação de dispositivos digitais que potencializem as aprendizagens na educação básica;

Os alunos do $5^{\circ}$ ano do ensino fundamental apresentam uma infinidade de competências e habilidades de um mundo digital que se confronta com as competências solicitadas pela/na escola, distanciando a formação escolar da formação na vida;

As atividades com uso das tecnologias digitais não são uma solução linear para os problemas de aprendizagens de leitura e escrita na escola, mas quando mediadas e intencionais possibilitam uma motivação e uma melhora gradativa das práticas de comunicação e produção de textual pelos alunos da educação básica.

Por fim, o estudo mostrou a importância da pesquisa-formação para o pensarfazer a prática docente na educação básica, uma vez que contribui com os multiletramentos das pesquisadoras, dos alunos e da professora da sala, campo de atuação da pesquisa, envolvendo-os em outras possibilidades de atuação didáticopedagógica nas práticas de leitura e escrita no contexto da cibercultura. Como todo estudo, muitos dilemas emergiram no processo mostrando a necessidade de aprofundamento do tema e da criação de outros dispositivos que possibilitem outras e novas interpretações sobre a ciberleitura na educação básica. Como nos diz Santaella (2013) se há um espaço que não pode ficar de fora desse novo cenário, esse espaço é a educação, cabe a nós a tessitura desse caminho. 


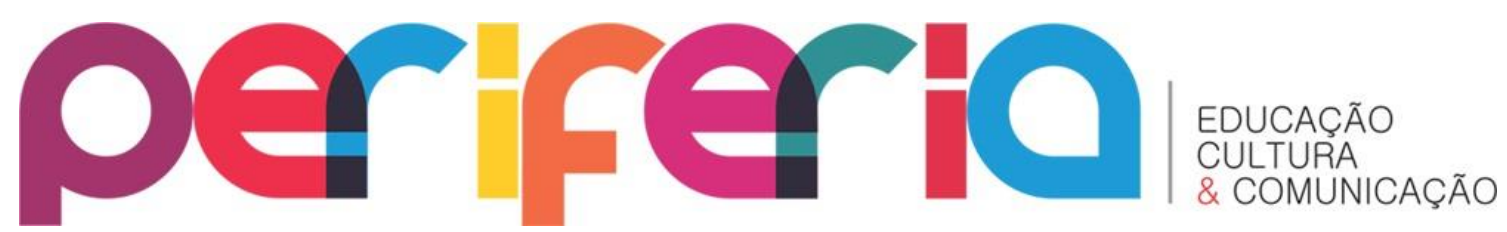

ISSN:1984-9540

DOI: 10.12957/periferia.2019.39384

\section{REFERENCIAS}

ALVES, Nilda. Decifrando o pergaminho - o cotidiano das escolas nas lógicas das redes cotidianas. In: OLIVEIRA, Inês Barbosa de; ALVES, Nilda. (Org.). Pesquisa no/do cotidiano das escolas: sobre redes de saberes. Rio de Janeiro: DP\&A, 2001.

ARDOINO, Jacques. Abordagem multirreferencial (plural) das situações educativas e formativas. In: BARBOSA, J. (Org.). Multirreferencialidade nas ciências e na educação. São Carlos: EdUFSCar, 1998. p. 24-41.

CERTEAU, M. de. A invenção do cotidiano: artes de fazer. Petrópolis: Editora Vozes, 2011.

CHARTIER, Roger. Os desafios da escrita. São Paulo: Unesp, 2002. Tradução Fulvia M. L. Morreto.

FREIRE, Paulo. A importância do ato de ler: em três artigos que se completam. 23. ed. São Paulo: Cortez, 1989.

KINCHELOE, Joe L.; BERRY, Kathleen S. Pesquisa em educação: conceituando a bricolagem. Porto Alegre: Artmed, 2007. Tradução Roberto Gataldo Costa.

MACEDO, Roberto Sidnei; GALEFFI, Dante; PIMENTEL, Álamo. Um rigor outro sobre a questão da qualidade na pesquisa qualitativa educação e ciências antropossociais: educação e ciências antropossociais. Salvador: UFBA., 2009. Disponível em:

<https://repositorio.ufba.br/ri/bitstream/ufba/206/1/Um\%20rigor\%20outro.pdf>. Acesso em: 30 jul. 2018.

MACEDO, Roberto Sidnei. Compreender/mediar a formação: o fundamento da educação. Brasilia: Liber Livro, 2010.

ROJO, Roxane Helena Multiletramentos na escola. Roxane Rojo, Eduardo Moura [orgs.]. São Paulo: Parábola editorial, 2012.

RIBEIRO, Mayra Rodrigues Fernandes. A sala de aula no contexto da cibercultura: formação docente e discente em atos de currículo. 2015. 207 f. Tese (Doutorado) Faculdade de Educação, Universidade do Estado do Rio de Janeiro, 2015. Disponível em: <http://www.bdtd.uerj.br/tde_busca/arquivo.php?codArquivo=9882>. Acesso em: 8 fev. 2018.

SANTAELLA, Lucia. O que é semiótica? São Paulo: Brasiliense, 2005. 131 p. , Lucia. Comunicação ubíqua: repercussões na cultura e na educação. São Paulo: Paulus, 2013. Coleção comunicação.

SANTOS, Edméa. Pesquisa-Formação na Cibercultura. Santo Tirso. Printhaus, 2014. 


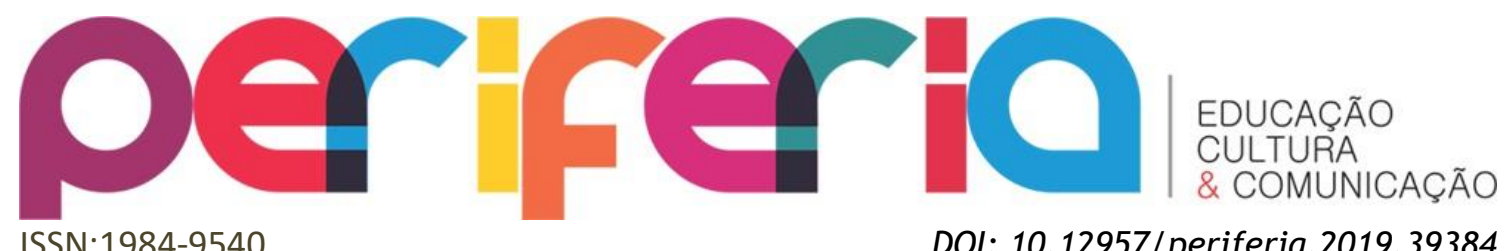

SERRES, Michel. Polegarzinha: Uma nova forma de viver em harmonia, de pensar as instituições, de ser e de saber. Rio de Janeiro: Bertrand Brasil, 2013.

SILVA, Marco. Sala de aula interativa. Rio de Janeiro: Quartet, 2003.

SOARES, Magda. Novas práticas de leitura e escrita: letramento na cibercultura. Educ. Soc. [online]. 2002, vol.23, n.81, p.143-160. Disponível em: < http: //www.scielo.br/pdf/es/v23n81/13935.pdf> Acesso em:29 de agosto 2018. 